\title{
Transfer of learning from simulated setting to the clinical setting: identifying instructional design features
}

\author{
Rasoul Masoomi ${ }^{1}$, Mohammad Shariati $^{2}$, Ali Labaf ${ }^{3}$, Azim Mirzazadeh $^{4} *$ (D) \\ Received: 27 Sep 2020 \\ Published: 14 Jul 2021
}

\begin{abstract}
Background: Transfer of learning (ToL) is the endpoint of simulation-based training (SBT). It is affected by numerous factors, which can be classified into 3 categories: learner characteristics, work environment, and training design. The first 2 have been identified to some extent in previous research. In this study, the aim was to identify the instructional design (ID) features affecting the ToL in SBT.

Methods: This qualitative study was conducted in 2 phases. Phase 1 covers thematic analysis of comparative studies in the field of SBT. A systematic search was performed on 6 databases of Ovid MEDLINE, EMBASE, PsycINFO, CENTRAL, Scopus, and Web of Science, and the references of related systematic reviews were also checked. In phase 2, semi-structured interviews were conducted with key informants (instructors and learners) and analyzed using directed content analysis. The results of the 2 phases were combined, and finally ID features of SBT were identified and categorized.

Results: In the first phase, 121 comparative studies were reviewed and in the second phase, 17 key informants were interviewed. After combining the results of the phases, the ID features affecting the ToL in SBT were classified into 3 broad categories and 15 subcategories as follows: (1) presimulation: preparation, briefing, and teaching cognitive base; (2) underlying theories: deliberate practice, mastery learning, and proficiency-based training; (3) and methods and techniques: distributed practice, variability, increasing complexity, opportunity for practice, repetitive practice, active learning, feedback/debriefing, simulator type, and simulator fidelity.

Conclusion: Although learning is transferred from the simulated setting to the clinical setting, this process is not automatic and straightforward. Numerous factors affect this transfer. The results of this research can be used in designing and evaluating the SBT programs.
\end{abstract}

Keywords: Simulation Training, Manikins, Transfer, Psychology, Education, Medical, Students, Medical

Conflicts of Interest: None declared

Funding: Tehran University of Medical Sciences

*This work has been published under CC BY-NC-SA 1.0 license.

Copyright $\odot$ Iran University of Medical Sciences

Cite this article as: Masoomi R, Shariati M, Labaf A, Mirzazadeh A. Transfer of learning from simulated setting to the clinical setting: identifying instructional design features. Med J Islam Repub Iran. 2021 (14 Jul);35:90. https://doi.org/10.47176/mjiri.35.90

\section{Introduction}

Simulation is "a technique that creates a situation or en-

Corresponding author: Dr Azim Mirzazadeh, mirzazad@tums.ac.ir

1. Department of Medical Education, Tehran University of medical Sciences, Tehran, Iran

2. Department of Community Medicine, Tehran University of medical Sciences, Tehran, Iran

3. Department of Emergency Medicine, Tehran University of medical Sciences, Tehran, Iran

4. Department of Internal Medicine, Department of Medical Education, Tehran University of Medical Sciences, Tehran, Iran vironment to allow persons to experience a representation

\section{$\uparrow$ What is "already known" in this topic:}

Transfer of learning is referred to as the endpoint of SBT. According to previous studies, learning is transferred from the simulated setting to the clinical setting. However, this process is not automatic and straightforward, because many factors affect it. Some of these factors, including feedback, repetitive practice, and variability, have already been identified.

$\rightarrow$ What this article adds:

In this study, by extensivelly searching databases and conducting interviews with key informants, 15 features of instructional design affecting transfer of learning were extracted. These features fall into 3 broad categories: presimulation; underlying theories; and methods and techniques. The results of this research can be used to design and evaluate simulation sessions. 
of a real event for the purpose of practice, learning, evaluation, testing, or to gain understanding of systems or human actions." (1). It facilitates any kind of learning, whether in the domai $n$ of cognitive, affective, and psychomotor, and allows learners to practice principles and skills in a controlled environment and learn to prepare themselves for safer patient care (2). Nowadays, instead of learning the skills on a patient in the clinical environment, students initially learn them on the simulator (3).

There are different methods and types of simulation, including full-body manikins, part-task trainers, screen based simulators, virtual reality, and simulated patients (2). Learning objectives, level of fidelity needed, and learning level of trainees are 3 influential factors in choosing the method and type of simulation (4).

The efficacy of simulation-based training (SBT) has been reported in many published systematic reviews and meta-analyses (5-8). Kirkpatrick's 4-level model is frequently used in the evaluation of educational programs and includes reaction, learning, behavior, and results (9). In SBT, the trainees' level of learning (a skill or knowledge) is evaluated in a simulated setting and on a simulator. However, SBT is effective when the learner is prepared to apply what $\mathrm{s} /$ he has learned in the simulated setting to real patients in the clinical setting. This is the third level of Kirkpatrick's model, that is, "behavior change," which is more specifically known as transfer of learning (10). As Norman et al expressed, 1 of the assumptions of SBT is that the skills learned through the simulator could be applied to the real patients (11). Nonetheless, the results of more than 30 years of research show that transfer of learning to the clinical setting is not an easy task (12).

Transfer of learning has a broad meaning and it has been supported by research for more than 120 years, especially in the literature of applied psychology and organizational learning (13). Contrary to the popular belief, transfer of learning has a complex and dynamic process, and it is affected by a set of factors (14). According to studies, the factors affecting transfer of learning are classified into 3 categories: learner characteristics, training design, and work environment (15). In the past, there was not much evidence regarding the transfer of learning; however, nowadays, it is strongly claimed that learning from the simulated setting can be transferred to the clinical setting (16-22). In fact, there have been debates over the utility of SBT for decades, that is, to understand whether or not simulation works. However, nowadays, the main question is how SBT works, and how we can design and implement it to maximize learning and facilitate transfer of learning (23).To this end, identifying the factors affecting transfer of learning is more important. As mentioned earlier, 3 categories of factors affect the transfer of learning; however, the purpose of this study is to find factors related to instructional design (ID), because the characteristics of the learners and factors related to the work environment have been identified and explained clearly in several previous studies (24-26).

\section{Methods}

This qualitative study was performed in 2 phases. The first phase included thematic analysis of comparative studies related to SBT, and the second was the directed content analysis of qualitative interviews with learners and instructors of SBT.

\section{Phase 1: Thematic Analysis of Comparative Studies Re-} lated to SBT

Review Question: Based on comparative studies, which features of instructional design related to SBT can affect the transfer of learning in undergraduate and postgraduate medical trainees?

Information Sources and Search Strategy: A systematic search was performed on 6 databases, including Ovid MEDLINE, EMBASE, PsycINFO, Cochrane Central Register of Controlled Trials (CENTRAL), Scopus, and Web of Science. Searching included free keywords and controlled terms. Terms and their derivatives were combined with appropriate Boolean operators. Wildcard and truncation operators were also used to increase search sensitivity. The search was conducted on August 12, 2019. Table 1 shows the search strategy developed for the Ovid MEDLINE database. This search strategy was adapted to other databases and modified as needed. In addition to searching the databases, the references of related systematic reviews were also examined. The Full search strategy for all databases is given in the Appendix S1.

Inclusion Criteria: All comparative studies (RCT, quasiexperimental, cohort, 1-group pretest-posttest studies) that met the following criteria were included in the study:

- Using SBT as the main intervention;

- Investigating undergraduate and postgraduate medical trainees;

- Assessing transfer of learning on the patients and in real clinical setting;

- Evaluating only technical skills and procedures;

- Comparative studies;

- Published only in English language.

Exclusion Criteria:

- Other health profession trainees;

- Qualitative, review, descriptive, and editorial studies;

- Nontechnical skills (such as leadership, teamwork, communication skills);

- Assessing learners' skills on a simulator or an animal or a human cadaver;

- Lack of full text of articles; and

- Published in a language other than English.

Selection of Studies: All retrieved articles were imported into EndNote X9 software. After removing duplicate records, the studies were selected through 3 screening stages. In title screening, clearly irrelevant articles were excluded from the review. Then, title and abstract screening was performed according to the inclusion and exclusion criteria. When there was no agreement on the abstracts or there was insufficient information, the full-texts of the articles were reviewed. Conflicts were resolved through discussion. 
Data Extraction and Analysis: Thematic analysis was used to find themes (instructional design features). The 5 stages of thematic analysis are familiarization with data, assigning the initial codes, searching for themes, reviewing the themes, and charting themes according to the objectives of the study (27). For this purpose, the Introduction and Methods sections of each article were carefully studied and the features related to the SBT instructional design were highlighted in the PDF file. Then, all the articles were imported into MAXDA 2018 software. Previously identified instructional design features, such as feedback, repetitive practice, and fidelity, were used as a starting point of theme classification, and new themes were added. Finally, the obtained themes (factors) were reviewed several times and categorized based on similarities.

In addition, basic study characteristics, such as source, year, study design, topic, learners, and sample size were extracted for each article.

\section{Phase 2: Directed Content Analysis of Qualitative In- terviews}

In order to emphasize the context and increase the strength of the study, in-person interviews were conducted with key informants. By "key informants" we mean all individuals who participated in the simulation sessions as learners or instructors. Instructors should have at least 2 years of teaching experience in SBT, and learners should have participated in at least 10 simulation sessions. Sampling was done completely purposefully. Participants of both genders, various disciplines, positions, and hospitals were selected for interview to maximize the variation of sampling. Individuals were called and invited to interview. If they accepted the invitation, the time and place of the interview were set. In the interview session, first, the purpose of the study was explained and a brief description was given about the concept of transfer of learning and related notions, and the interview was audio recorded with the consent of participants. The overall structure of the questions was clear because directed content analysis had been used for data analysis. Since numerous factors had been obtained from the previous stage, the questions were in line with those questions. Meanwhile, some open-ended questions were asked to identify other factors, especially with regard to the context. In the interview session, first, an open-ended question was asked. For example, the following questions were asked from the instructors and learners, respectively:

- "What factors affect the process of transferring technical skills learned in the simulated environment to the real patient?"

- "Have you experienced transfer of learning? If yes, what were the factors behind this transfer?"

This was followed by more detailed and exploratory questions using predefined codes and levels. After each interview, the data were implemented, and directed content analysis was performed on them, and subsequent interviews were conducted based on them. Interviews continued until data saturation.

The set of codes (factors) identified from the first phase of the research was used as a guide for coding the text of the interviews. Therefore, whenever a text was related to the previously identified factors, the same code was assigned to it. New codes were also emerged and stored separately in the MAXQDA software. The codes were reviewed several times, and after being summarized, they were placed in the preexisting categories or in the new category based on similarity and appropriateness.

\section{Results}

\section{Phase 1}

The process of study selection is presented in Figure 1 . After removing duplicates, 14,620 records remained. Then, 10,773 articles in the title screening and 3,445 articles in the abstract screening were excluded. Next, 295 studies were excluded by full-text screening, leaving 107 studies for final review. After reviewing the reference list of systematic reviews, 14 new articles were obtained. Therefore, a total of 121 articles were reviewed.

The characteristics of the articles and their full reference lists have been presented in a table in the Appendix S2 and S3. The studies had been published between 1987 and 2019 in 74 different journals. In addition, journals of surgery and anesthesia played a major role in publishing these articles.

In total, 10 one-group pretest-posttest studies, 10 cohort studies, 10 quasi-experimental studies, and 91 (75\%) true experimental (RCT) studies were included in the review. Most of the studies (46\%) were 2-group pretest-posttest and 2-group posttest only (37\%). Also, 81\% (91) of study participants were postgraduate medical trainees (PGMT), $21 \%$ (18) undergraduate medical trainees (UGMT), and $3.3 \%$ (4) a mix of PGMT and UGMT. Minimally invasive surgeries/procedures, Central Venous Catheter (CVC) insertion, and intubation were the most commonly taught clinical topics using simulation.

Table 1 (in the Appendix S4) shows the ID features that lead to the transfer of learning in SBT. In total, 3 broad categories of factors affecting learning transfer were identified: presimulation, underlying theories, and methods and techniques. Each of these categories have their own subcategories that are described below.

\section{Presimulation}

Briefing: In this session, the instructor explains the objectives of the session, the duration of the training, the role of the learners, and the teaching method. Defining the roles and tasks is especially important for group and scenario-based simulation sessions. Also, if there is a simulator or medical device that students are not familiar with, it should be introduced and described. The briefing takes place just before the simulation session $(1,28)$. Briefing sessions were reported in 23 (19\%) studies.

Teaching Cognitive Base: Before starting the simulation, learners should be familiar with the theoretical and cognitive base of the procedure. Items, such as the importance and necessity of the procedure, anatomy, indications, contraindications, and steps to perform the procedure should be described. This section can be presented in 


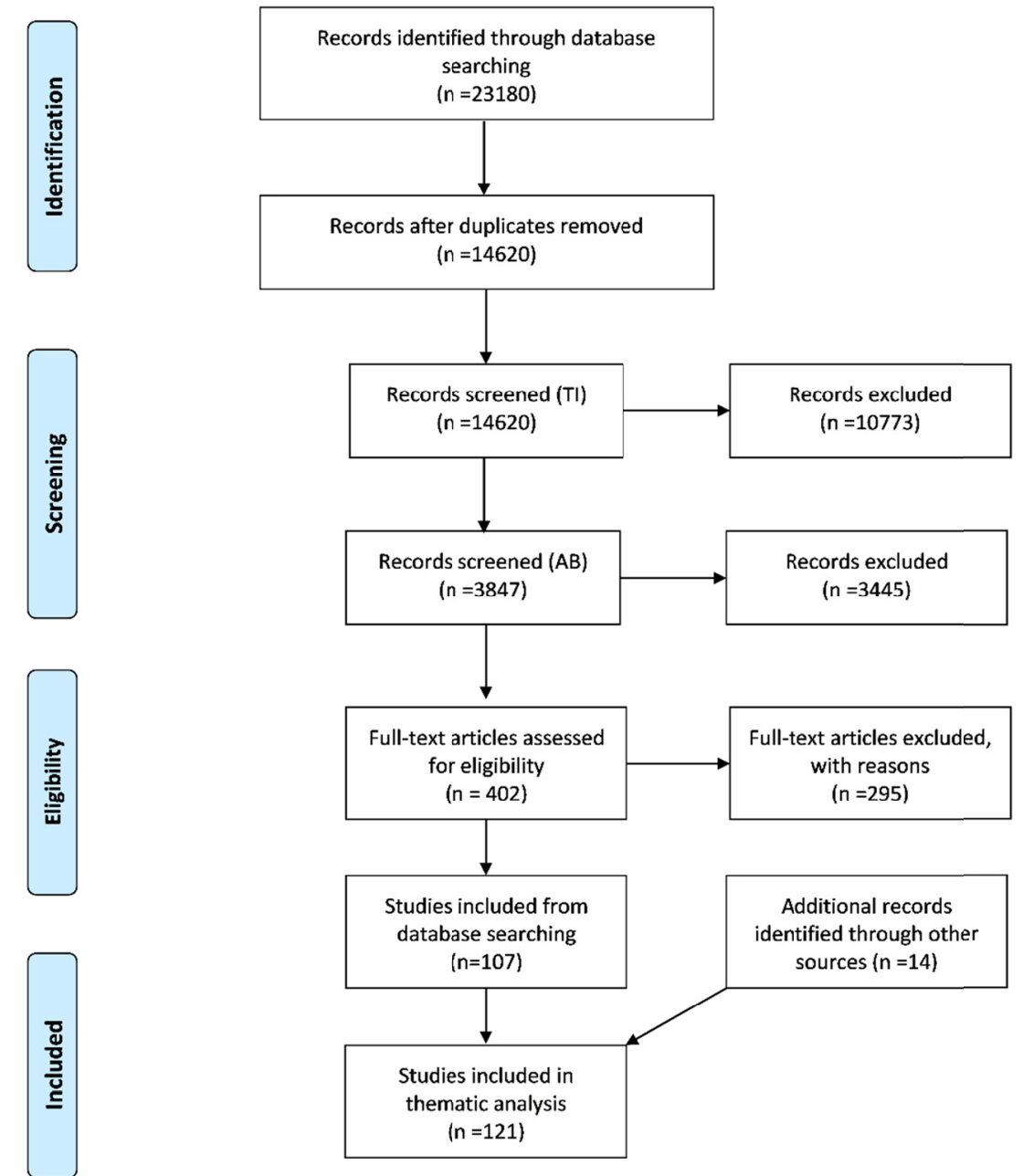

Fig. 1. Flow diagram illustrating the study selection process.

the form of text, videos, e-learning, lectures, et cetera (29). In $64(52.8 \%)$ interventions, teaching the theoretical dimension of procedures was reported. In 42 (34.7\%) interventions, the procedure technique was shown as a preprepared film before starting the simulation operation. The cognitive dimension could be presented several days before the simulation or in the simulation session or before the start of the simulation operation. No specific information was extracted from the reports.

\section{Underlying Theories}

Deliberate Practice (DP): This theory was developed by Ericsson et al. According to them, significant improvements in performance occur when the following cases are met: The objectives of the task are well defined, individuals are motivated to progress, they receive feedback and adequate opportunities for repetition, and gradual modification of their performance is provided (30).

Nine features or requirements of DP in simulation-based medical education are as follows: (1) learners with high motivation and good concentration; (2) engaging in a well-defined goal or task; (3) appropriate difficulty level of the tasks; (4) frequent and focused training; (5) accurate assessment; (6) informative feedback from educational resources (eg, simulator and teacher); (7) learners monitoring their own learning experiences and review and correct strategies, errors, and levels of learning, and reengage in DP if necessary; (8) learners are evaluated for competency; (9) learners are allowed to go to the next level/unit.

The effect of DP on learning and its transfer in simulation has been well documented. However, not all the above 9 features have been necessarily observed in all articles. Mostly, they included 3 phases of practice, informative feedback, and reinforcement. In total, this method was used in $11(9 \%)$ studies to learn the skills. It is noteworthy that most of these articles merged mastery learning (ML) and DP.

Mastery Learning (ML): ML is not a new approach and it dates back to the 1950s and 1960s; it is the brainchild of John Carroll and Benjamin Bloom. According to this approach, if all learners are given ample opportunity, all of them can achieve all or most of the learning outcomes at the mastery level (31). ML is a rigorous type of compe- 


\begin{tabular}{llc} 
Table 1. Search Strategy for Ovid MEDLINE & \\
\hline Row & Syntax & $\mathrm{N}$ \\
\hline 1 & simulation.ab,ti. & 175122 \\
2 & simulator?.ab,ti. & 18054 \\
3 & manikin?.ab,ti. & 2711 \\
4 & mannikin?.ab,ti. & 62 \\
5 & mannequin?.ab,ti. & 1610 \\
6 & exp Simulation Training/ & 7701 \\
7 & Patient Simulation/ & 4738 \\
8 & High Fidelity Simulation Training/ & 185 \\
9 & exp Computer Simulation/ & 223787 \\
10 & virtual reality.ab,ti. & 8250 \\
11 & Virtual Reality/ & 1044 \\
12 & augmented reality.ab,ti. & 1529 \\
13 & exp Education, Medical/ & 158221 \\
14 & educat\$.ti,ab. & 546268 \\
15 & train\$.ti,ab. & 493886 \\
16 & learn\$.ti,ab. & 359073 \\
17 & instruct $\$ . t i, a b$. & 89094 \\
18 & teach\$.ti,ab. & 178995 \\
19 & curricul\$.ti,ab. & 51461 \\
20 & 1 or 2 or 3 or 4 or 5 or 6 or 7 or 8 or 9 or 10 or 11 & 367730 \\
21 & 13 or 14 or 15 or 16 or 17 or 18 or 19 & 1436455 \\
22 & 20 and 21 & 38476 \\
23 & exp Clinical Study/ or comparative study/ & 2527306 \\
24 & 22 and 23 & 5046 \\
25 & limit 24 to english language & 4941 \\
\hline & &
\end{tabular}

tency-based education. In ML, the educational outcomes are the same (with little or no difference), but the training time may be different among learners (32).

ML is a set of 7 complementary features as follows:

1. Initial or diagnostic test;

2. Clearly defined learning activities, arranged in units from easy to difficult;

3. Educational activities;

4. Determining the minimum accepted standard;

5. Formative evaluation with practical feedback to ensure the achievement of the minimum acceptance standard (acceptable level of mastery);

6. Proceed to the next training unit based on the evaluation result; otherwise,

7. Continue training until the desired level of mastery is achieved (33).

In $11(9 \%)$ cases of the interventions, simulations were performed using the ML approach.

Proficiency-based Training (PBT): PBT is conceptually very similar to $\mathrm{ML}$, although there are some differences. First, it is used to help learning certain technical skills. Second, it is the most common term and paradigm in surgical simulation, and is therefore primarily used in the surgical education literature (34). In the PBT approach, the end point of teaching a technical skill is when the individual has a performance similar to that of an expert. Learning experiences of trainees are tailored to their individual needs. This means that, like ML, the time to complete the training and the number of practices and repetitions are different for each person (35). The important point in this approach is to determine the level of proficiency. This level is determined by the experts. In our research, the simulator used in this approach was mostly virtual reality. Therefore, these levels have already been embedded as a program by simulator developers. In 49
$(40.49 \%)$ studies, simulation interventions were performed with PBT approach. Considering the topics covered, we find that almost all of the interventions were about 1 of the minimally invasive surgeries/ procedures (MIS). Therefore, we can conclude that MIS (skill), PBT (training approach), and virtual reality (simulator type) are completely interrelated. This means that combining them increases learning and transfer of learning.

\section{Methods and Techniques}

Feedback and Debriefing: In simulation, feedback refers to information given or dialogue between participants, facilitators (instructors), simulator, or peers to improve understanding of concepts or aspects of performance (28). Feedback is very important in simulation, and some scholars believe that if we remove feedback from the simulation, almost no learning will happen (36). Feedback was reported in $86(71 \%)$ studies, but the sources of feedback were as follows:

- Instructor or facilitator $(46 ; 38 \%)$;

- Simulator $(66 ; 54.5 \%)$;

- Haptic feedback $(40 ; 33 \%)$;

- Audiovisual feedback (23;19\%);

- Unknown $(3 ; 2.47 \%)$.

Haptic feedback is particularly relevant to virtual reality simulators. This type of feedback can be used to simulate contact, touching a limb or part of the body, and cutting (1). A number of studies have reported more than 1 source of feedback, so the sum of the percentages of feedback sources is greater than the feedback itself. In simulation, there are generally 2 types of feedback: one is duringsession feedback, which can occur immediately, and the other is end-of-session feedback (including debriefing). Immediate feedback is most effective in teaching individual procedural skills, and if final feedback is provided, it can help increase learning and transfer of learning (37). The term debriefing is specific to team simulation training, which is based on guidelines, such as ACLS, ATLS, PALS, et cetera. Some consider feedback and debriefing as completely separate concepts, but some simulation articles refer to group feedback at the end of a session as debriefing. Debriefing is essentially a reflection and 1 of the most important factors in the transfer of learning in studies related to resuscitation training. Feedback was provided in $68(56.19 \%)$ papers during the simulation session and in $23(19 \%)$ papers at the end of the simulation session. The procedures taught in these 121 articles were mostly of individual type; hence, the number of feedbacks during the sessions was higher than end-of-session ones.

Distributed Practice: This method is in contrast to massed practice. According to this method, to teach a skill, it is better to divide the practice into shorter sessions over a longer period of time (38).For example, if we have 8 hours to teach a skill, instead of an 8 -hour session, we can hold it in the form of four 2-hour sessions. This method is widely used in the approaches of DB, ML, and PBT. In this study, we considered simulation interventions as a distributed practice when they were held in more than 1 session/day. Thus, the distributed practice method was 
used in most (71\%) of the interventions.

Repetitive Practice: Repetitive practice is a basic principle in learning any technical skill. In fact, repetitive practice quickly automates skills, and the key is to transfer skills from the simulator to the real patient (39). It should also be noted that, if it is embedded in DP, it would be more effective than unstructured and thoughtless practice. Nevertheless, repetitive practice helps learn the skills, especially in novices. Once the learning curve reaches the plateau level, the routine repetition of a skill no longer improves one's performance, in which case the principles of DP should be used $(40,41)$. Repetitive practice was reported in $72(56.19 \%)$ papers. Our criterion for the repetitive practice was performing a task on the simulator for more than 1 time.

Increasing Complexity: If we break down the steps of a procedure or task from simple to complex and gradually increase its difficulty, the learning of skills will be easier for learners, especially novices (39). Although this approach could be implemented in the scenario-based simulations, it was observed that, in the reviewed studies, MIS procedures had been mainly taught with virtual reality simulators. In total, $42(34.7 \%)$ cases of the interventions used the technique of gradually increasing complexity to teach skills.

Variability: Variability simply refers to the use of a variety of practices to teach a particular concept or skill. For example, instead of executing and practicing a specific scenario for 5 times, it is better to have a different scenario each time, but the task is the same. In other words, this diversity is about the surface features of a task. For example, when describing a particular clinical symptoms, we can give examples of patients of different ages, genders, races, and medical histories (42). In scenario-based simulation training, this variety of practices can be considered in the scenario itself. Moreover, in advanced simulators, such as full-body manikins and virtual reality, this practice may be embedded as a program in the simulator itself. In the present study, most of the studies that received the variability code used virtual reality simulators for training. Overall, $26(21.48 \%)$ studies used the variability technique.

Simulator Fidelity: Simulator fidelity is one of the challenging topics. It is usually divided into 3 categories: low, medium, and high fidelity. It simply means the realism level of the simulator, and how similar it is to the real world (1). High-fidelity simulators have long been thought to improve transfer of learning, but various studies have shown that transfer of learning does not depend solely on the level of fidelity. In general, educational goals, type of procedure, and level of learners determine the fidelity of a simulator (11). By simulator fidelity, we actually mean physical fidelity. Nowadays, this term is used to mean simulation itself, in which case the simulator is only one of its components. In this view, in addition to the simulator fidelity, there are at least 2 other kinds of fidelity: environmental fidelity and psychological fidelity.

Environmental Fidelity: To what extent does the simulated environment (simulator, room, tools, equipment, moulage, and sensory prop) represent the reality and ap- pearance of the real environment?

Psychological Fidelity: To what extent does the simulated environment stimulate the underlying psychological processes required in the real environment? In fact, it is the level of realism perceived by learners (11).

No specific information was extracted from environmental and psychological fidelity of the experimental studies. Regarding the physical fidelity of the simulator, although most of the educational interventions (68 cases; $56.19 \%)$ used high-fidelity simulators, in $26(21.48 \%)$ cases they used low-fidelity simulators, such as task trainers; they also showed transfer of learning. A combination of them was used in $5(4.13 \%)$ studies. The remaining studies did not report the type of fidelity.

Simulator Type: Virtual reality simulators were used in $65(53.71 \%)$ interventions; task trainer simulators in 23 (19\%); full-body manikins in $6(4.95 \%)$, and box trainers in $6(4.95 \%)$. Finally, in $8(6.61 \%)$ interventions, a combination of simulators was used. Also, some studies did not report the type of simulator.

\section{Phase 2}

A total of 17 participants were interviewed. The minimum and maximum interview durations were 25 minutes and 65 minutes (average duration $=41$ minutes). Demographic information of participants is presented in the Appendix S5. Through directed content analysis, a total of 98 initial and open codes (including codes obtained from phase 1) were identified. One of the aims of qualitative directed content analysis is to see whether the findings show evidence of support or nonsupport for a phenomenon. Thus, the following question was raised:

- From the interviewees' point of view, do the existing factors influence the transfer of learning meaningful to them?

In phase 1 of the study, a total of 12 factors related to instructional design in transfer of learning were extracted. Two of these factors were also confirmed in interviews (feedback and teaching cognitive base). Since there was no experience for some factors, practically no specific information was obtained. For example, there was no teaching or learning experience by ML, PBT, or DP. However, 3 categories and several subcategories were extracted from the interviews in addition to the previous 12 factors.

\section{Feedback Source}

In the interviews, in addition to the instructor and the simulator, peer feedback was extracted as one of the main sources of feedback in the simulation sessions. In this regard, 1 student said:

"If I know, for example, that my peer knows the content very well, and the teacher is very busy, I may ask my peer to help me learn a skill. Then, I can practice it in front of the instructor and get his/her feedback. Overall, I personally get a lot of feedback from my peers."

\section{Preparation}

It includes items such as choosing the appropriate time and location for training, scenario design, et cetera. 


\section{Appropriate Time}

"The time of the class is also important. For example, when our simulation sessions are scheduled at 4 PM or 5 $P M$, then it seems as if it is not part of our curriculum...."

\section{Appropriate Location}

"... I do not think it is a good idea to hold our classes in the stressful situation of the hospital."

\section{Predesigned Scenario}

"Depending on the year of the residency, we run 3 different scenarios. For example, if we are going to teach resuscitation. There is a simple resuscitation practice for $P G Y 1$ residents and a more complicated one for PGY3 ones (like infants' resuscitation).

\section{Opportunity for Practice}

"But at the end, I came to the conclusion that a simulation workshop would not be complete unless every single person sitting there would eventually run the procedure once."

\section{Active Learning}

"The teacher should involve the learners and constantly ask them questions. Sometimes, our simulation classes are not different from the theory classes; they are spiritless. I attended a simulation class at a hospital. It was very good; there were few learners and the teacher gave us a complete feedback."

Similarities Between Learning Environment and Transfer Environment

"The more the environment or simulator is similar to the clinical environment, the better. Of course, the instructor can also play a major role. That means s/he can help get closer to the real environment."

Integration of the Results of the 2 Phases of the Study

As mentioned earlier, fidelity is divided into 3 categories: physical, environmental, and psychological. Thus, the category "similarity between learning environment and transfer environment" was merged with environmental fidelity. In Phase 1, the instructor and the simulator were identified as 2 sources of feedback, and in the interviews, a peer was added. Preparation was placed under the general category of presimulation, and the opportunity for practice and active learning was included in the category of methods and techniques. Therefore, in 2 phases of the study, 15 features of instructional design that are effective in transferring learning from the simulated setting to the clinical setting were extracted. These 15 features were classified into 3 general categories (Table 2).

\section{Discussion}

Many factors are influencing the transfer of learning from the simulated environment to the clinical environment. In previous studies, these factors were not clearly and comprehensively identified. As a result, in this study, we identified these factors using a 2-phase study. These factors, which are the characteristics of ID, were classified into 3 general categories: presimulation, underlying theories, and methods and techniques. Some of the above factors overlap, which means that if we use one 1 approach, it automatically covers some other factors as well. For example, if we use the ML approach, factors such as feedback, repetitive practice, and increasing complexity are embedded in it. However, this does not mean that these factors can be used only with these approaches. There are many studies that have used only repetitive practice or feedback without performing all the steps of ML. In general, the above factors have a positive effect on learning and transfer of learning. However, if they are utilized in the form of a coherent approach, such as ML and PBT, they can be more effective. If we consider the transfer of learning as the end point and measure of the effectiveness of any educational intervention, SBT meets this criterion; and the review of 121 comparative studies (75\% were RCTs) confirmed this issue.

It was reconfirmed that a wide range of skills and procedures can be taught using simulation techniques. This can include complex procedures like laparoscopy cholecystectomy (43) and simple procedures, such as injections. The important point is to identify and use the factors affecting learning and transfer of learning in SBT(23).

Although the transfer of learning has been extensively studied by cognitive psychologists and educational specialists for more than a century, it has rarely been considered by medical educators (44). According to Dyre and Tolsgaard, there are many articles in medical education confirming that transfer of learning can occur, but few studies explore when, why, and how the transfer can be optimized theoretically and conceptually (45). In other words, the transfer of learning in medical education is taken for granted, while various studies in the field of medical education have repeatedly shown that this field is a challenging task for both students and teachers (46).

\begin{tabular}{lc} 
Table 2. ID Features That Lead to the Transfer of Learning in SBT \\
\hline Presimulation & Methods \& Techniques \\
Preparation & Distributed practice \\
Briefing & Variability \\
Teaching cognitive base & Increasing complexity \\
Underlying theories & Opportunity for practice \\
Deliberate practice & Repetitive practice \\
Mastery learning & Active learning \\
Proficiency-based training & Feedback/debriefing \\
& Simulator type \\
& Simulator fidelity \\
\hline
\end{tabular}


When most lessons are taught outside the clinical setting, instructors need to devise a method to design the curriculum so that the learning can be transferred to the real environment (47).

A number of factors affecting the transfer of learning that were obtained in this study were similar to those reported in previous studies $(39,48,49)$. However, the present study was different from them in 4 major aspects:

1. Only studies that really measured the transfer of learning were examined;

2. The strength of evidence was relatively high $(75 \%$ were RCTs[randomized controlled trials]);

3. The number of factors extracted was higher than the previous studies and were classified into 3 categories;

4. By conducting a qualitative interview, issues related to context were also considered.

In this study, all simulation modalities (patient simulations, VR, etc.) and all medical trainees' levels (undergraduate and postgraduate) were included, which may have ignored their particular conditions and requirements.

\section{Conclusion}

Although transfer of learning from a simulated environment to a clinical setting is done regularly, this process does not occur automatically and directly. In general, 3 categories of factors, including learner-related factors, factors related to educational design, and factors related to clinical environment have an impact on transfer of learning. In this study, only factors related to educational design were extracted from comparative studies and qualitative interviews. Each of these 16 factors can be explored in more depth in future studies. Experimental studies as well as systematic reviews are recommended. The results of this research can be used in designing simulation-based medical education programs as well as evaluating these programs.

\section{Acknowledgment}

Special thanks to all the faculty members and learners who participated in the research.

\section{Conflict of Interests}

The authors declare that they have no competing interests.

\section{References}

1. Lopreiato JO. Healthcare simulation dictionary: Agency for Healthcare Research and Quality; 2016.

2. Weller JM, Nestel D, Marshall SD, Brooks PM, Conn JJ. Simulation in clinical teaching and learning. Med J Aust. 2012;196(9):594.

3. Irvine S, Martin J. Bridging the gap: from simulation to clinical practice. Clin Teach. 2014;11(2):94-8.

4. Harden RM, Laidlaw JM. Essential skills for a medical teacher: an introduction to teaching and learning in medicine: Elsevier Health Sciences; 2020.

5. Cook DA, Brydges R, Hamstra SJ, Zendejas B, Szostek JH, Wang AT, et al. Comparative effectiveness of technology-enhanced simulation versus other instructional methods: a systematic review and metaanalysis. Simul Healthc. 2012;7(5):308-20.

6. Cook DA, Hatala R, Brydges R, Zendejas B, Szostek JH, Wang AT, et al. Technology-enhanced simulation for health professions education: a systematic review and meta-analysis. JAMA. 2011;306(9):978-88.
7.Lorello GR, Cook DA, Johnson RL, Brydges R. Simulation-based training in anaesthesiology: a systematic review and meta-analysis. $\mathrm{Br}$ J Anaesth. 2014;112(2):231-45.

8. McGaghie WC, Issenberg SB, Cohen MER, Barsuk JH, Wayne DB. Does simulation-based medical education with deliberate practice yield better results than traditional clinical education? A meta-analytic comparative review of the evidence. Acad Med. 2011;86(6):706.

9. Kirkpatrick DL, Kirkpatrick JD. Evaluating training programs: the four levels. 3rd ed. San Francisco, CA: Berrett-Koehler; 2006.

10. de Melo BCP, Rodrigues Falbo A, Sorensen JL, van Merriënboer JJ, van der Vleuten C. Self-perceived long-term transfer of learning after postpartum hemorrhage simulation training. Int J Gynaecol Obstet. 2018;141(2):261-7.

11. Norman G, Dore K, Grierson L. The minimal relationship between simulation fidelity and transfer of learning. Med Educ. 2012;46(7):636-47.

12. Teteris E, Fraser K, Wright B, McLaughlin K. Does training learners on simulators benefit real patients? Adv Health Sci Educ Theory Pract. 2012;17(1):137-44.

13. Heaven C, Clegg J, Maguire P. Transfer of communication skills training from workshop to workplace: the impact of clinical supervision. Patient Educ Couns. 2006;60(3):313-25.

14. Peters S, Clarebout G, Diemers A, Delvaux N, Verburgh A, Aertgeerts B, et al. Enhancing the connection between the classroom and the clinical workplace: a systematic review. Perspect Med Educ. 2017;6(3):148-57.

15. Ford JK, Baldwin TT, Prasad J. Transfer of training: The known and the unknown. Ann Rev Organiz Psychol Organiz Behav. 2018;5:20125 .

16. Buckley CE, Kavanagh DO, Traynor O, Neary PC. Is the skillset obtained in surgical simulation transferable to the operating theatre? Am J Surg. 2014;207(1):146-57.

17. Cosman PH, Hugh TJ, Shearer CJ, Merrett ND, Biankin AV, Cartmill JA. Skills acquired on virtual reality laparoscopic simulators transfer into the operating room in a blinded, randomised, controlled trial. Stud Health Technol Inform. 2007;125:76-81.

18. Dawe SR, Pena GN, Windsor JA, Broeders JA, Cregan PC, Hewett PJ, et al. Systematic review of skills transfer after surgical simulationbased training. Br J Surg. 2014;101(9):1063-76.

19. Howells NR, Gill HS, Carr AJ, Price AJ, Rees JL. Transferring simulated arthroscopic skills to the operating theatre: a randomised blinded study. J Bone Joint Surg. 2008;90(4):494-9.

20. Hseino H, Nugent E, Lee MJ, Hill AD, Neary P, Tierney S, et al. Skills transfer after proficiency-based simulation training in superficial femoral artery angioplasty. Simul Healthc. 2012;7(5):274-81.

21. Spiliotis AE, Spiliotis PM, Palios IM. Transferability of SimulationBased Training in Laparoscopic Surgeries: A Systematic Review. Minim Invasive Surg. 2020;2020.

22. Sturm LP, Windsor JA, Cosman PH, Cregan P, Hewett PJ, Maddern GJ. A systematic review of skills transfer after surgical simulation training. Ann Surg. 2008;248(2):166-79.

23. Kneebone R, Nestel D, Bello F. Learning in a simulated environment. In: Dent JA, Harden RM, Hunt D, Hodges BD, editors. A Practical Guide for Medical Teachers. 5 ed. Philadelphia: Elsevier; 2017.

24. Blume BD, Ford JK, Baldwin TT, Huang JL. Transfer of training: A meta-analytic review. Journal of Management. 2010;36(4):1065-105.

25. Burke LA, Hutchins HM. Training Transfer: An Integrative Literature Review. Hum Resource Develop Rev. 2007;6(3):263-96.

26. Tonhäuser C, Büker L. Determinants of Transfer of Training: A Comprehensive Literature Review. Int $J$ Res Voc Educ Train. 2016;3(2):127-65.

27. Kiger ME, Varpio L. Thematic analysis of qualitative data: AMEE Guide No. 131. Med Teach. 2020;42(8):846-54.

28. Meakim C, Boese T, Decker S, Franklin AE, Gloe D, Lioce L, et al. Standards of best practice: Simulation standard I: Terminology. Clin Simul Nurs. 2013;9(6):S3-S11.

29. Grantcharov TP, Reznick RK. Teaching procedural skills. BMJ. 2008;336(7653):1129-31.

30. Ericsson KA. Acquisition and maintenance of medical expertise: a perspective from the expert-performance approach with deliberate practice. Acad Med. 2015;90(11):1471-86.

31. Guskey TR. Mastery Learning. In: Seel NM, editor. Encyclopedia of the Sciences of Learning. Boston, MA: Springer US; 2012.

32. McGaghie WC, Issenberg SB, Barsuk JH, Wayne DB. A critical 
review of simulation-based mastery learning with translational outcomes. Med Educ. 2014;48(4):375-85.

33. McGaghie WC, Issenberg SB, Petrusa ER, Scalese RJ. A critical review of simulation-based medical education research: 2003-2009. Med Educ. 2010;44(1):50-63.

34. Patnaik R, Stefanidis D. Outcome-Based Training and the Role of Simulation. In: Stefanidis D, Korndorffer Jr JR, Sweet R, editors. Comprehensive Healthcare Simulation: Surgery and Surgical Subspecialties. Cham: Springer International Publishing; 2019.

35. Gallagher AG, Ritter EM, Champion H, Higgins G, Fried MP, Moses $\mathrm{G}$, et al. Virtual reality simulation for the operating room: proficiencybased training as a paradigm shift in surgical skills training. Ann Surg. 2005;241(2):364.

36. Boyle E, Al-Akash M, Gallagher AG, Traynor O, Hill AD, Neary PC. Optimising surgical training: use of feedback to reduce errors during a simulated surgical procedure. Postgrad Med J. 2011;87(1030):524-8.

37. Zevin B, Levy JS, Satava RM, Grantcharov TP. A consensus-based framework for design, validation, and implementation of simulationbased training curricula in surgery. J Am Coll Surg. 2012;215(4):5806. e3.

38. Mitchell EL, Lee DY, Sevdalis N, Partsafas AW, Landry GJ, Liem TK, et al. Evaluation of distributed practice schedules on retention of a newly acquired surgical skill: a randomized trial. Am J Surg. 2011;201(1):31-9.

39. Barry Issenberg S, Mcgaghie WC, Petrusa ER, Lee Gordon D, Scalese RJ. Features and uses of high-fidelity medical simulations that lead to effective learning: a BEME systematic review. Med Teach. 2005;27(1):10-28

40. Koenig A, Iseli M, Wainess R, Lee JJ. Assessment methodology for computer-based instructional simulations. Mil Med. 2013;178(suppl_10):47-54.

41. McGaghie WC, Issenberg SB, Petrusa ER, Scalese RJ. Effect of practice on standardised learning outcomes in simulation-based medical education. Med Educ. 2006;40(8):792-7.

42. Van Merriënboer JJ, Sweller J. Cognitive load theory in health professional education: design principles and strategies. Med Educ. 2010;44(1):85-93.

43. Palter VN, Grantcharov TP. Individualized deliberate practice on a virtual reality simulator improves technical performance of surgical novices in the operating room: a randomized controlled trial. Ann Surg. 2014;259(3):443-8.

44. Castillo JM, Park YS, Harris I, Cheung JJH, Sood L, Clark MD, et al. A critical narrative review of transfer of basic science knowledge in health professions education. Med Educ. 2018;52(6):592-604.

45. Dyre L, Tolsgaard MG. The gap in transfer research. Med Educ. 2018;52(6):580-2

46. Kulasegaram KM, McConnell M. When I say... transfer-appropriate processing. Med Educ. 2016;50(5):509.

47. Grierson L, Norman G, Monteiro S, Sibbald M. Simulation-Based Education and the Challenge of Transfer. In: Chiniara G, editor. Clinical Simulation. 2nd ed: Academic Press; 2019. p. 115-27.

48. Norman G. Teaching basic science to optimize transfer. Med Teach. 2009;31(9):807-11.

49. Spruit EN, Band GP, Hamming JF, Ridderinkhof KR. Optimal training design for procedural motor skills: a review and application to laparoscopic surgery. Psychol Res. 2014;78(6):878-91. 
Appendix S1. Full Search Strategy for Six Databases

1- Ovid MEDLINE(R) and Epub Ahead of Print, In-Process \& Other Non-Indexed Citations, Daily and Versions (R) 1946 to August 09, 2019 Search date: 12 August 2019

\begin{tabular}{|c|c|c|}
\hline Row & Syntax & $\mathrm{N}$ \\
\hline 1 & simulation.ab,ti. & 175122 \\
\hline 2 & simulator?.ab,ti. & 18054 \\
\hline 3 & manikin?.ab,ti. & 2711 \\
\hline 4 & mannikin?ab,ti. & 62 \\
\hline 5 & mannequin?.ab,ti. & 1610 \\
\hline 6 & exp Simulation Training/ & 7701 \\
\hline 7 & Patient Simulation/ & 4738 \\
\hline 8 & High Fidelity Simulation Training/ & 185 \\
\hline 9 & exp Computer Simulation/ & 223787 \\
\hline 10 & virtual reality.ab,ti. & 8250 \\
\hline 11 & Virtual Reality/ & 1044 \\
\hline 12 & augmented reality.ab,ti. & 1529 \\
\hline 13 & exp Education, Medical/ & 158221 \\
\hline 14 & educat\$.ti,ab. & 546268 \\
\hline 15 & train\$.ti,ab. & 493886 \\
\hline 16 & learn\$.ti,ab. & 359073 \\
\hline 17 & instruct\$.ti,ab. & 89094 \\
\hline 18 & teach\$.ti,ab. & 178995 \\
\hline 19 & curricul\$.ti,ab. & 51461 \\
\hline 20 & 1 or 2 or 3 or 4 or 5 or 6 or 7 or 8 or 9 or 10 or 11 & 367730 \\
\hline 21 & 13 or 14 or 15 or 16 or 17 or 18 or 19 & 1436455 \\
\hline 22 & 20 and 21 & 38476 \\
\hline 23 & exp Clinical Study/or comparative study/ & 2527306 \\
\hline 24 & 22 and 23 & 5046 \\
\hline 25 & limit 24 to english language & 4941 \\
\hline
\end{tabular}

2- Embase 1974 to 2019 Week 32 (OvidSP)

Search date: 12 August 2019

\begin{tabular}{|c|c|c|}
\hline Row & Syntax & $\mathrm{N}$ \\
\hline 1 & simulation.ab,ti. & 187436 \\
\hline 2 & simulator?.ab,ti. & 23800 \\
\hline 3 & manikin?.ab,ti. & 3949 \\
\hline 4 & mannikin?.ab,ti. & 83 \\
\hline 5 & mannequin?.ab,ti. & 2491 \\
\hline 6 & exp Simulation Training/ & 3916 \\
\hline 7 & Patient Simulation/ & 756 \\
\hline 8 & High Fidelity Simulation Training/ & 265 \\
\hline 9 & exp simulation/ & 278975 \\
\hline 10 & exp Computer Simulation/ & 112145 \\
\hline 11 & virtual reality.ab,ti. & 10979 \\
\hline 12 & Virtual Reality/ & 15315 \\
\hline 13 & augmented reality.ab,ti. & 1852 \\
\hline 14 & 1 or 2 or 3 or 4 or 5 or 6 or 7 or 8 or 9 or 10 or 11 or 12 or 13 & 395646 \\
\hline 15 & exp medical education/ & 300492 \\
\hline 16 & educat\$.ti,ab. & 716976 \\
\hline 17 & train\$.ti,ab. & 654469 \\
\hline 18 & learn\$.ti,ab. & 467062 \\
\hline 19 & instruct\$.ti,ab. & 121097 \\
\hline 20 & teach\$.ti,ab. & 229201 \\
\hline 21 & curricul\$.ti,ab. & 65579 \\
\hline 22 & 15 or 16 or 17 or 18 or 19 or 20 or 21 & 1914304 \\
\hline 23 & 14 and 22 & 55340 \\
\hline 24 & exp comparative study/ or exp controlled study/ & 7869395 \\
\hline 25 & 23 and 24 & 13595 \\
\hline 26 & limit 25 to (english language and embase and journal) & 7849 \\
\hline
\end{tabular}


3- PsycINFO 1967 to August Week 12019 (OvidSP)

\begin{tabular}{|c|c|c|}
\hline Row & Syntax & $\mathrm{N}$ \\
\hline 1 & simulation.ab,ti. & 27376 \\
\hline 2 & simulator?.ab,ti. & 4290 \\
\hline 3 & manikin?.ab,ti. & 354 \\
\hline 4 & mannikin?.ab,ti. & 22 \\
\hline 5 & mannequin?.ab,ti. & 174 \\
\hline 6 & exp Simulation/ & 59868 \\
\hline 7 & exp Computer Simulation/ & 15149 \\
\hline 8 & exp Virtual Reality/ & 7920 \\
\hline 9 & exp Augmented Reality/ & 398 \\
\hline 10 & virtual reality.ab,ti. & 4648 \\
\hline 11 & augmented reality.ab,ti. & 587 \\
\hline 12 & 1 or 2 or 3 or 4 or 5 or 6 or 7 or 8 or 9 or 10 or 11 & 78768 \\
\hline 13 & exp Medical Education/ & 23000 \\
\hline 14 & educat\$.ti,ab. & 431270 \\
\hline 15 & train\$.ti,ab. & 282152 \\
\hline 16 & learn\$.ti,ab. & 413163 \\
\hline 17 & instruct\$.ti,ab. & 124043 \\
\hline 18 & teach\$.ti,ab. & 246927 \\
\hline 19 & curricul\$.ti,ab. & 56215 \\
\hline 20 & 13 or 14 or 15 or 16 or 17 or 18 or 19 & 1062791 \\
\hline 21 & 12 and 20 & 22287 \\
\hline 22 & medical.ab,ti. & 177550 \\
\hline 23 & medicine.ab,ti. & 51166 \\
\hline 24 & healthcare.ab,ti. & 38430 \\
\hline 25 & physician?.ab,ti. & 57399 \\
\hline 26 & health profession? ab,ti. & 3042 \\
\hline 27 & 22 or 23 or 24 or 25 or 26 & 271975 \\
\hline 28 & 21 and 27 & 1626 \\
\hline 29 & limit 28 to ("0300 clinical trial" or "0400 empirical study") & 1035 \\
\hline 30 & limit 29 to (peer reviewed journal and english language) & 765 \\
\hline
\end{tabular}

4- EBM Reviews - Cochrane Central Register of Controlled Trials July 2019 (OvidSP)

\begin{tabular}{|c|c|c|}
\hline Row & Syntax & $\mathrm{N}$ \\
\hline 1 & simulation.ab,ti. & 6052 \\
\hline 2 & simulator?.ab,ti. & 2315 \\
\hline 3 & manikin?.ab,ti. & 1178 \\
\hline 4 & mannikin?.ab,ti. & 11 \\
\hline 5 & mannequin?.ab,ti. & 366 \\
\hline 6 & Patient Simulation/ & 450 \\
\hline 7 & exp Computer Simulation/ & 1511 \\
\hline 8 & virtual reality.ab,ti. & 2315 \\
\hline 9 & augmented reality.ab,ti. & 128 \\
\hline 10 & 1 or 2 or 3 or 4 or 5 or 6 or 7 or 8 or 9 & 11404 \\
\hline 11 & exp Education, Medical/ & 3074 \\
\hline 12 & educat\$.ti,ab. & 54046 \\
\hline 13 & train\$.ti,ab. & 86835 \\
\hline 14 & learn\$.ti,ab. & 25476 \\
\hline 15 & instruct\$.ti,ab. & 21877 \\
\hline 16 & teach\$.ti,ab. & 17313 \\
\hline 17 & curricul\$.ti,ab. & 3893 \\
\hline 18 & 11 or 12 or 13 or 14 or 15 or 16 or 17 & 164977 \\
\hline 19 & 10 and 18 & 5258 \\
\hline 20 & limit 19 to english language & 4250 \\
\hline
\end{tabular}




\section{5- Scopus}

Search date: 12 August 2019

( ( TITLE-ABS ( simulation OR simulator? OR manikin? OR mannikin? OR mannequin? OR "virtual reality" OR "augmented reality" )) AND ( INDEXTERMS ( "Simulation Training" OR "Patient Simulation" OR "High Fidelity Simulation Training" OR "Computer Simulation" OR " Virtual Reality") ) AND ( INDEXTERMS ( "medical education" OR "education, medical") OR TITLE-ABS ( educat* OR learn* OR train* OR teach* OR instuct* OR curricul*)) ) AND ( ( INDEXTERMS ( "clinical trials" OR "clinical trials as a topic" OR "randomized controlled trial" OR "Randomized Controlled Trials as Topic" OR "controlled clinical trial" OR "Controlled Clinical Trials" OR "random allocation" OR "Double-Blind Method" OR "Single-Blind Method" OR "Cross-Over Studies" OR "Placebos" OR "multicenter study" OR "double blind procedure" OR "single blind procedure" OR "crossover procedure" OR "clinical trial" OR "controlled study" OR "randomization" OR "placebo") ) OR ( TITLE-ABS-KEY ( ( "clinical trials" OR "clinical trials as a topic" OR "randomized controlled trial" OR "Randomized Controlled Trials as Topic" OR "controlled clinical trial" OR "Controlled Clinical Trials as Topic" OR "random allocation" OR "randomly allocated" OR "allocated randomly" OR "Double-Blind Method" OR "Single-Blind Method" OR "Cross-Over Studies" OR "Placebos" OR "crossover trial" OR "single blind" OR "double blind" OR "factorial design" OR "factorial trial")) ) OR ( TITLE-ABS ( clinical AND trial* OR trial* OR rct* OR random* OR blind*))) AND (LIMIT-TO (LANGUAGE, "English")) AND ( LIMIT-TO ( SRCTYPE, "j" )) 3403

6- Web of Science core collection

1983-2019

- $\quad$ Science Citation Index Expanded (SCI-EXPANDED) --1983-present

- $\quad$ Social Sciences Citation Index (SSCI) --1983-present

- $\quad$ Emerging Sources Citation Index (ESCI) --2015-present

Search date: 12 August 2019

$\mathrm{TS}=($ simulation OR simulator? OR manikin? OR mannikin? OR mannequin? OR "virtual reality" OR "augmented reality") AND TS=("medical education" OR educat* OR learn* OR train* OR teach* OR instuct* OR curricul*) AND TS= ("clinical trial" OR "comparative study" OR "controlled trial")

Indexes=SCI-EXPANDED, SSCI, ESCI Timespan=All years

1972

Appendix S2- Study Characteristics of Included Papers

\begin{tabular}{|c|c|c|c|c|c|c|}
\hline Source & Journal & Study Design & Is RCT? & Topics & Trainees & $\mathrm{N}$ \\
\hline 1- (Ewy GA, et al.,1987) & Academic Medicine & $2 \mathrm{PP}$ & No & Physical examination & UGME & 116,92 \\
\hline $\begin{array}{l}\text { 2- (Ovassapian A, et } \\
\text { al.,1988) }\end{array}$ & British journal of anaesthesia & $2 \mathrm{PP}$ & Yes & Intubation & PGME & 16,16 \\
\hline 3- (From RP, et al.,1994) & Anesthesia and analgesia & $2 \mathrm{PP}$ & Yes & Airway Management & UGME & 49,48 \\
\hline 4- (Peugnet F, et al.,1998) & Computer Aided Surgery & $2 \mathrm{PP}$ & Yes & laser coagulation & PGME & 5,3 \\
\hline 5- (Tuggy ML,1998) & $\begin{array}{l}\text { The journal of the American } \\
\text { board of family practice }\end{array}$ & $2 \mathrm{PO}$ & Yes & Flexible sigmoidoscopy & PGME & 5,5 \\
\hline 6- (Scott DJ, et al.,2000) & $\begin{array}{l}\text { Journal of the American } \\
\text { College of Surgeons }\end{array}$ & $2 \mathrm{PP}$ & Yes & laparoscopic cholecystectomy & PGME & 9,13 \\
\hline $\begin{array}{l}\text { 7- (Hamilton EC, et } \\
\text { al.,2001) }\end{array}$ & American journal of surgery & $2 \mathrm{PP}$ & Yes & laparoscopic hernia repair & PGME & 10,11 \\
\hline 8- (Naik VN, et al.,2001) & Anesthesiology & $2 \mathrm{PP}$ & Yes & Intubation & PGME & 12,12 \\
\hline 9- (Ost D, et al.,2001) & $\begin{array}{c}\text { American journal of respira- } \\
\text { tory and critical care medi- } \\
\text { cine }\end{array}$ & $2 \mathrm{PO}$ & Yes & bronchoscopy & PGME & 3,3 \\
\hline 10- (Edmond CV, Jr.,2002) & Laryngoscope & $2 \mathrm{PO}$ & $\mathrm{NO}$ & endoscopic sinus surgery & PGME & 2,2 \\
\hline $\begin{array}{l}\text { 11- (Hamilton EC, et } \\
\text { al.,2002) }\end{array}$ & $\begin{array}{c}\text { Surgical Endoscopy and } \\
\text { Other Interventional Tech- } \\
\text { niques }\end{array}$ & $1 \mathrm{PP}$ & NO & laparoscopic cholecystectomy & PGME & 19 \\
\hline 12- (Rowe R, et al.,2002) & Anesthesia \& Analgesia & $2 \mathrm{PP}$ & Yes & Intubation & PGME & 12,8 \\
\hline $\begin{array}{l}\text { 13-(Seymour NE, et } \\
\text { al.,2002) }\end{array}$ & Annals of surgery & $2 \mathrm{PO}$ & Yes & laparoscopic cholecystectomy & PGME & 8,8 \\
\hline 14- (Gerson LB, et al.,2003) & Endoscopy & $2 \mathrm{PP}$ & Yes & Sigmoidoscopy & PGME & 9,7 \\
\hline $\begin{array}{l}\text { 15- (Gormley GJ, et } \\
\text { al.,2003) }\end{array}$ & $\begin{array}{l}\text { Annals of the rheumatic } \\
\text { diseases }\end{array}$ & $2 \mathrm{PP}$ & Yes & shoulder injection & UGME & 20,20 \\
\hline 16- (Lee SK, et al.,2003) & Journal of trauma & $2 \mathrm{PP}$ & Yes & trauma assessment & PGME & 30,30 \\
\hline $\begin{array}{l}\text { 17- (Abrahamson S, et } \\
\text { al.,2004) }\end{array}$ & $\begin{array}{l}\text { Quality \& Safety in Health } \\
\text { Care }\end{array}$ & $2 \mathrm{PO}$ & Yes & Intubation & PGME & 5,5 \\
\hline 18- (Blum MG, et al.,2004) & Annals of thoracic surgery & $2 \mathrm{PO}$ & Yes & Bronchoscopy & PGME & 5,5 \\
\hline $\begin{array}{l}\text { 19- (Di Giulio E, et } \\
\text { al.,2004) }\end{array}$ & Gastrointestinal endoscopy & $2 \mathrm{PO}$ & Yes & upper gastrointestinal endoscopy & PGME & 11,11 \\
\hline $\begin{array}{l}\text { 20- (Grantcharov TP, et } \\
\text { al.,2004) }\end{array}$ & British journal of surgery & $2 \mathrm{PP}$ & Yes & Laparoscopic cholecystectomy & PGME & 8,8 \\
\hline
\end{tabular}




\begin{tabular}{|c|c|c|c|c|c|c|}
\hline Source & Journal & $\begin{array}{l}\text { Study De- } \\
\text { sign }\end{array}$ & $\begin{array}{c}\text { Is } \\
\text { RCT? }\end{array}$ & Topics & Trainees & $\overline{\mathrm{N}}$ \\
\hline $\begin{array}{l}\text { 21- (Sedlack RE, et } \\
\text { al.,2004) }\end{array}$ & $\begin{array}{l}\text { American journal of gastro- } \\
\text { enterology }\end{array}$ & $2 \mathrm{PO}$ & Yes & colonoscopy & PGME & 4,4 \\
\hline $\begin{array}{l}\text { 22- (Sedlack RE, et } \\
\text { al.,2004) }\end{array}$ & $\begin{array}{l}\text { Clinical Gastroenterology } \\
\text { and Hepatology }\end{array}$ & $2 \mathrm{PO}$ & Yes & flexible sigmoidoscopy & PGME & 19,19 \\
\hline 23- (Ahlberg G, et al.,2005) & Endoscopy & $2 \mathrm{PO}$ & Yes & Colonoscopy & PGME & 6,6 \\
\hline $\begin{array}{l}\text { 24- (Hochberger J, et } \\
\text { al.,2005) }\end{array}$ & Gastrointestinal endoscopy & $2 \mathrm{PP}$ & Yes & upper gastrointestinal endoscopy & PGME & 9,5 \\
\hline $\begin{array}{l}\text { 25- (Schijven MP, et } \\
\text { al.,2005) }\end{array}$ & Surgical Endoscopy & $\mathrm{CO}$ & - & laparoscopic cholecystectomy & PGME & 12,12 \\
\hline 26- (Stitik TP, et al.,2005) & $\begin{array}{l}\text { American journal of physical } \\
\text { medicine \& rehabilitation }\end{array}$ & $2 \mathrm{PP}$ & Yes & injection skills & PGME & 15,15 \\
\hline 27- (Banks E, et al.,2006) & $\begin{array}{l}\text { American Journal of Obstet- } \\
\text { rics and Gynecology }\end{array}$ & $2 \mathrm{PP}$ & Yes & episiotomy repair & PGME & 12,12 \\
\hline 28- (Chaer RA, et al.,2006) & Annals of Surgery & $2 \mathrm{PO}$ & Yes & Peripheral Catheterization & PGME & 10,10 \\
\hline 29- (Cohen J, et al.,2006) & Gastrointestinal Endoscopy & $2 \mathrm{PO}$ & Yes & Colonoscopy & PGME & 23,22 \\
\hline $\begin{array}{l}\text { 30- (Scerbo MW, et } \\
\text { al.,2006) }\end{array}$ & Journal of Infusion Nursing & $2 \mathrm{PP}$ & Yes & intravenous (IV) procedures & UGME & 12,14 \\
\hline 31- (Ahlberg G, et al.,2007) & American Journal of Surgery & $2 \mathrm{PP}$ & Yes & laparoscopic cholecystectomy & PGME & 7,6 \\
\hline 32- (Banks EH, et al.,2007) & $\begin{array}{l}\text { American Journal of Obstet- } \\
\text { rics and Gynecology }\end{array}$ & $2 \mathrm{PP}$ & Yes & laparoscopic tubal ligation & PGME & 10,10 \\
\hline $\begin{array}{l}\text { 33- (Cosman PH, et } \\
\text { al.,2007) }\end{array}$ & $\begin{array}{l}\text { Studies in Health Technology } \\
\text { and Informatics }\end{array}$ & $2 \mathrm{PO}$ & Yes & Laparoscopic skills & PGME & 5,5 \\
\hline $\begin{array}{l}\text { 34- (Miranda JA, et } \\
\text { al.,2007) }\end{array}$ & Journal of Hospital Medicine & $2 \mathrm{PO}$ & No & $\begin{array}{l}\text { central venous catheter (CVC) inser- } \\
\text { tion }\end{array}$ & PGME & 16,38 \\
\hline 35- (Park J, et al.,2007) & American Journal of Surgery & $2 \mathrm{PP}$ & Yes & colonoscopy & PGME & 12,12 \\
\hline 36- (Shavit I, et al.,2007) & $\begin{array}{l}\text { Archives of Pediatrics and } \\
\text { Adolescent Medicine }\end{array}$ & $2 \mathrm{PO}$ & No & Procedural sedation & PGME & 16,16 \\
\hline $\begin{array}{l}\text { 37- (Thomas-Gibson S, et } \\
\text { al.,2007) }\end{array}$ & Endoscopy & $1 \mathrm{PP}$ & No & colonoscopy & PGME & 21 \\
\hline $\begin{array}{l}\text { 38- (Draycott TJ, et } \\
\text { al.,2008) }\end{array}$ & Obstetrics and Gynecology & $1 \mathrm{PP}$ & NO & Shoulder dystocia & Both & 254 \\
\hline $\begin{array}{l}\text { 39- (Howells NR, et } \\
\text { al.,2008) }\end{array}$ & $\begin{array}{c}\text { Journal of bone and joint } \\
\text { surgery }\end{array}$ & $2 \mathrm{PO}$ & Yes & arthroscopic skills & PGME & 10,10 \\
\hline $\begin{array}{l}\text { 40- (Ossowski KL, et } \\
\text { al.,2008) }\end{array}$ & Laryngoscope & $2 \mathrm{PO}$ & Yes & Laryngoscopy & UGME & 10,10 \\
\hline $\begin{array}{l}\text { 41- (Van Sickle KR, et } \\
\text { al.,2008) }\end{array}$ & $\begin{array}{l}\text { Journal of the American } \\
\text { College of Surgeons }\end{array}$ & 2PP & Yes & Laparoscopic skills & PGME & 11,11 \\
\hline 42- (Wayne DB, et al.,2008) & Chest & $2 \mathrm{PO}$ & No & Advanced Cardiac Life Support & PGME & 38,40 \\
\hline 43- (Yi SY, et al.,2008) & $\begin{array}{c}\text { Studies in Health Technology } \\
\text { and Informatics }\end{array}$ & $2 \mathrm{PO}$ & No & colonoscopy & PGME & 5,6 \\
\hline 44- (Barsuk JH, et al.,2009) & $\begin{array}{l}\text { Archives of Internal Medi- } \\
\text { cine }\end{array}$ & $\mathrm{CO}$ & No & $\begin{array}{l}\text { central venous catheter (CVC) inser- } \\
\text { tion }\end{array}$ & PGME & 92,92 \\
\hline 45- (Barsuk JH, et al.,2009) & Journal of Hospital Medicine & $\mathrm{CO}$ & No & $\begin{array}{l}\text { central venous catheter (CVC) inser- } \\
\text { tion }\end{array}$ & PGME & 28,13 \\
\hline 46- (Barsuk JH, et al.,2009) & Critical Care Medicine & $\mathrm{CO}$ & No & $\begin{array}{l}\text { central venous catheter (CVC) inser- } \\
\text { tion }\end{array}$ & PGME & 76,27 \\
\hline 47- (Britt RC, et al.,2009) & American Journal of Surgery & $2 \mathrm{PO}$ & Yes & $\begin{array}{c}\text { central venous catheter (CVC) inser- } \\
\text { tion }\end{array}$ & PGME & 13,21 \\
\hline $\begin{array}{l}\text { 48- (Domuracki KJ, et } \\
\text { al.,2009) }\end{array}$ & Resuscitation & $2 \mathrm{PO}$ & Yes & cricoid pressure & UGME & 53,48 \\
\hline $\begin{array}{l}\text { 49- (Friedman Z, et } \\
\text { al.,2009) }\end{array}$ & $\begin{array}{l}\text { Regional Anesthesia and } \\
\text { Pain Medicine }\end{array}$ & $2 \mathrm{PP}$ & Yes & Epidural anesthesia & PGME & 12,12 \\
\hline 50- (Gaies MG, et al.,2009) & Pediatrics & $2 \mathrm{PP}$ & Yes & $\mathrm{BMV}, \mathrm{CVC}, \mathrm{LP}$ & PGME & 18,18 \\
\hline 51- (Hogle NJ, et al.,2009) & Surgical Endoscopy & $2 \mathrm{PO}$ & Yes & laparoscopic cholecystectomy & PGME & 6,6 \\
\hline 52- (Larsen CR, et al.,2009) & BMJ & $2 \mathrm{PO}$ & Yes & laparoscopic skills & PGME & 11,10 \\
\hline $\begin{array}{l}\text { 53- (Mohan PVR, et } \\
\text { al.,2009) }\end{array}$ & $\begin{array}{l}\text { Medical Journal Armed } \\
\text { Forces India }\end{array}$ & $2 \mathrm{PP}$ & Yes & laparoscopic cholecystectomy & PGME & 12,12 \\
\hline 54- (Sotto JA, et al.,2009) & $\begin{array}{c}\text { Studies in Health Technology } \\
\text { and Informatics }\end{array}$ & $2 \mathrm{PO}$ & Yes & Peripheral venous cannulation & UGME & 20,20 \\
\hline $\begin{array}{l}\text { 55- (Bruppacher HR, et } \\
\text { al.,2010) }\end{array}$ & Anesthesiology & 2PP & Yes & weaning from bypass & PGME & 10,10 \\
\hline 56- (Butter J, et al.,2010) & $\begin{array}{c}\text { Journal of General Internal } \\
\text { Medicine }\end{array}$ & $2 \mathrm{PO}$ & No & Cardiac auscultation (Physical exam) & UGME & 77,31 \\
\hline
\end{tabular}




\begin{tabular}{|c|c|c|c|c|c|c|}
\hline Source & Journal & $\begin{array}{l}\text { Study } \\
\text { Design }\end{array}$ & $\begin{array}{c}\text { Is } \\
\text { RCT? }\end{array}$ & Topics & Trainees & $\mathrm{N}$ \\
\hline 57- (Evans LV, et al.,2010) & Academic Medicine & $2 \mathrm{PO}$ & Yes & $\begin{array}{c}\text { central venous catheter (CVC) } \\
\text { insertion }\end{array}$ & PGME & 90,95 \\
\hline 58- (Ferlitsch A, et al.,2010) & Endoscopy & $2 \mathrm{PO}$ & Yes & $\begin{array}{c}\text { upper gastrointestinal endosco- } \\
\text { py }\end{array}$ & PGME & 14,14 \\
\hline 59- (Fried MP, et al.,2010) & $\begin{array}{l}\text { Otolaryngology--head and } \\
\text { neck surgery }\end{array}$ & $2 \mathrm{PO}$ & Yes & Endoscopic sinus surgery & PGME & 12,13 \\
\hline 60- (Gauger PG, et al.,2010) & American Journal of Surgery & $2 \mathrm{PO}$ & Yes & laparoscopic skills & PGME & 7,7 \\
\hline 61- (Haycock A, et al.,2010) & Gastrointestinal Endoscopy & $2 \mathrm{PO}$ & Yes & colonoscopy & Both & 18,18 \\
\hline $\begin{array}{l}\text { 62- (Kallstrom R, et } \\
\text { al.,2010) }\end{array}$ & Journal of Endourology & $1 \mathrm{PP}$ & No & $\begin{array}{c}\text { Transurethral Resection of } \\
\text { Prostate }\end{array}$ & PGME & 24 \\
\hline 63- (Lenchus JD,2010) & $\begin{array}{l}\text { Journal of the American } \\
\text { Osteopathic Association }\end{array}$ & $1 \mathrm{PP}$ & No & $\begin{array}{l}\text { CVC, LP, paracentesis, thora- } \\
\text { centesis }\end{array}$ & both & 60 \\
\hline 64- (Schout BM, et al.,2010) & BJU International & $2 \mathrm{PO}$ & Yes & cystourethroscopy & UGME & 50,50 \\
\hline 65- (Sroka G, et al.,2010) & American Journal of Surgery & $2 \mathrm{PP}$ & Yes & Laparoscopic Cholecystectomy & PGME & 8,8 \\
\hline $\begin{array}{l}\text { 66- (Tongprasert F, et } \\
\text { al.,2010) }\end{array}$ & Prenatal Diagnosis & $\mathrm{CO}$ & No & Cordocentesis & UGME & 5,5 \\
\hline $\begin{array}{l}\text { 67- (Wahidi MM, et } \\
\text { al.,2010) }\end{array}$ & Chest & $\mathrm{CO}$ & No & bronchoscopy & PGME & 22,22 \\
\hline 68- (De Ponti R, et al.,2011) & $\begin{array}{l}\text { Journal of the American } \\
\text { College of Cardiology }\end{array}$ & $2 \mathrm{PO}$ & Yes & transseptal catheterization & PGME & 7,7 \\
\hline 69-(Ghaderi I, et al.,2011) & American Journal of Surgery & $1 \mathrm{PP}$ & No & $\begin{array}{l}\text { laparoscopic incisional hernia } \\
\text { repair (LIHR) }\end{array}$ & PGME & 14 \\
\hline 70- (Johnson SJ, et al.,2011) & Human Factors & $2 \mathrm{PO}$ & Yes & $\begin{array}{c}\text { Interventional Radiology pro- } \\
\text { cedures }\end{array}$ & PGME & 7,7 \\
\hline 71- (Khouli H, et al.,2011) & Chest & $2 \mathrm{PP}$ & Yes & $\begin{array}{c}\text { Central venous catheter (CVC) } \\
\text { insertion }\end{array}$ & PGME & 24,23 \\
\hline 72- (Palter VN, et al.,2011) & Annals of Surgery & 2PP & Yes & Abdominal fascial closure & PGME & 9,9 \\
\hline 73- (Zendejas B, et al.,2011) & Annals of Surgery & $2 \mathrm{PP}$ & Yes & $\begin{array}{l}\text { laparoscopic inguinal hernia } \\
\text { repair }\end{array}$ & PGME & 26,24 \\
\hline 74- (Ahya SN, et al.,2012) & Seminars in Dialysis & $1 \mathrm{PP}$ & No & Hemodialysis catheter insertion & PGME & 12 \\
\hline 75- (Bagai A, et al.,2012) & $\begin{array}{c}\text { Circulation Cardiovascular } \\
\text { interventions }\end{array}$ & $2 \mathrm{PP}$ & Yes & Cardiac Catheterization & PGME & 11,15 \\
\hline 76- (Ende A, et al.,2012) & Gastrointestinal Endoscopy & 2PP & Yes & diagnostic upper endoscopy & PGME & $10,9,9$ \\
\hline $\begin{array}{l}\text { 77- (Franzeck FM, et } \\
\text { al.,2012) }\end{array}$ & Surgical Endoscopy & $2 \mathrm{PP}$ & Yes & laparoscopic camera navigation & UGME & 12,12 \\
\hline 78- (Fried MP, et al.,2012) & $\begin{array}{l}\text { Archives of otolaryngology-- } \\
\text { head \& neck surgery }\end{array}$ & $2 \mathrm{PP}$ & No & Endoscopic sinus surgery & PGME & 8,6 \\
\hline 79- (Hseino H, et al.,2012) & Simulation in healthcare & $2 \mathrm{PO}$ & Yes & endovascular skills & PGME & 5,5 \\
\hline 80- (Orzech N, et al.,2012) & Annals of Surgery & $2 \mathrm{PP}$ & Yes & laparoscopic suturing skills & PGME & 10,10 \\
\hline 81- (Palter VN, et al.,2012) & Annals of Surgery & $2 \mathrm{PO}$ & Yes & laparoscopic colorectal surgery & PGME & 9,9 \\
\hline 82- (Stather DR, et al.,2012) & Respirology & $\mathrm{CO}$ & No & Bronchoscopy & PGME & 4,4 \\
\hline 83- (White ML, et al.,2012) & Pediatric Emergency Care & $1 \mathrm{PP}$ & No & lumbar puncture & PGME & 21 \\
\hline 84- (Daly MK, et al.,2013) & $\begin{array}{l}\text { Journal of Cataract and Re- } \\
\text { fractive Surgery }\end{array}$ & $2 \mathrm{PO}$ & Yes & Cataract Extraction & PGME & 11,10 \\
\hline 85- (Gala R, et al.,2013) & Obstetrics and Gynecology & 2PP & Yes & laparoscopic skills & PGME & 48,54 \\
\hline 86- (Palter VN, et al.,2013) & Annals of Surgery & $2 \mathrm{PP}$ & Yes & Laparoscopic Cholecystectomy & PGME & 10,10 \\
\hline 87- (Pokroy R, et al.,2013) & $\begin{array}{l}\text { Graefes Archive for Clinical } \\
\text { and Experimental Ophthal- } \\
\text { mology }\end{array}$ & $\mathrm{CO}$ & No & cataract surgery & PGME & 10,10 \\
\hline 88- (Todsen T, et al.,2013) & BMC Medical Education & $2 \mathrm{PO}$ & Yes & Urethral catheterization & UGME & 17,14 \\
\hline 89- (Balci MBC, et al.,2014) & Nobel medicus & $2 \mathrm{PO}$ & Yes & Laparoscopic Skills & PGME & 8,8 \\
\hline 90- (Bansal VK, et al.,2014) & Journal of Surgical Education & $2 \mathrm{PP}$ & Yes & laparoscopic cholecystectomy & PGME & 9,8 \\
\hline $\begin{array}{l}\text { 91- (Cannon WD, et } \\
\text { al.,2014) }\end{array}$ & $\begin{array}{c}\text { Journal of Bone and Joint } \\
\text { Surgery }\end{array}$ & $2 \mathrm{PP}$ & Yes & arthroscopic knee surgery & PGME & 27,21 \\
\hline 92- (Edrich T, et al.,2014) & $\begin{array}{c}\text { Journal of Cardiothoracic and } \\
\text { Vascular Anesthesia }\end{array}$ & $2 \mathrm{PP}$ & Yes & echocardiography & PGME & 23,23 \\
\hline 93- (Ferrero NA, et al.,2014) & Anesthesiology & $2 \mathrm{PP}$ & Yes & $\begin{array}{l}\text { Transesophageal Echocardiog- } \\
\text { raphy }\end{array}$ & PGME & 21,21 \\
\hline 94- (Hong P, et al.,2014) & $\begin{array}{l}\text { International Journal of Pedi- } \\
\text { atric Otorhinolaryngology }\end{array}$ & $2 \mathrm{PP}$ & Yes & $\begin{array}{l}\text { Myringotomy and tympanosto- } \\
\text { my tube insertion (MT) }\end{array}$ & UGME & 13,11 \\
\hline $\begin{array}{l}\text { 95- (McIntosh KS, et } \\
\text { al.,2014) }\end{array}$ & $\begin{array}{c}\text { Canadian Journal of Gastro- } \\
\text { enterology \& Hepatology }\end{array}$ & $2 \mathrm{PP}$ & No & colonoscopy & PGME & 10,8 \\
\hline
\end{tabular}




\begin{tabular}{|c|c|c|c|c|c|c|}
\hline Source & Journal & $\begin{array}{c}\text { Study } \\
\text { Design }\end{array}$ & $\begin{array}{c}\text { Is } \\
\text { RCT? }\end{array}$ & Topics & Trainees & $\mathrm{N}$ \\
\hline 96- (Minai F, et al.,2014) & $\begin{array}{l}\text { Journal of Anaesthesiology, } \\
\text { Clinical Pharmacology }\end{array}$ & $2 \mathrm{PO}$ & Yes & intubation & UGME & 28,29 \\
\hline 97- (Palter VN, et al.,2014) & Annals of Surgery & $2 \mathrm{PP}$ & Yes & Laparoscopic Cholecystectomy & PGME & 8,8 \\
\hline 98- (Udani AD, et al.,2014) & $\begin{array}{c}\text { Anesthesiology Research and } \\
\text { Practice }\end{array}$ & $2 \mathrm{PP}$ & Yes & subarachnoid blocks (SAB) & PGME & 11,10 \\
\hline 99- (Grover SC, et al.,2015) & Gastrointestinal Endoscopy & $2 \mathrm{PP}$ & Yes & colonoscopy & PGME & 16,17 \\
\hline 100- (Koch AD, et al.,2015) & Gastrointestinal Endoscopy & $2 \mathrm{PP}$ & Yes & colonoscopy & PGME & 8,10 \\
\hline 101- (Peltan ID, et al.,2015) & Simulation in healthcare & $2 \mathrm{PP}$ & Yes & $\begin{array}{l}\text { Central Venous Catheter (CVC) } \\
\text { Insertion }\end{array}$ & PGME & 36,37 \\
\hline $\begin{array}{l}\text { 102- (Tolsgaard MG, et } \\
\text { al.,2015) }\end{array}$ & Medical Education & $2 \mathrm{PP}$ & Yes & Ultrasonography & UGME & 16,14 \\
\hline 103-(Aloosh M, et al.,2016) & Journal of Endourology & $1 \mathrm{PP}$ & No & Ureteroscopy & PGME & 5 \\
\hline 104- (Arias T, et al.,2016) & $\begin{array}{l}\text { International Journal of Gy- } \\
\text { naecology and Obstetrics }\end{array}$ & $2 \mathrm{PO}$ & Yes & vaginal examination & UGME & 66,21 \\
\hline $\begin{array}{l}\text { 105- (Asoglu MR, et } \\
\text { al.,2016) }\end{array}$ & $\begin{array}{l}\text { Journal of the Turkish- } \\
\text { German Gynecological As- } \\
\text { sociation }\end{array}$ & $\mathrm{CO}$ & No & hysterectomy & PGME & 75,98 \\
\hline 106- (Jaffer U, et al.,2016) & Journal of Surgical Education & $1 \mathrm{PP}$ & No & Ultrasonography & UGME & 24 \\
\hline $\begin{array}{l}\text { 107- (Thawani JP, et } \\
\text { al.,2016) }\end{array}$ & $\begin{array}{c}\text { Journal of Clinical Neurosci- } \\
\text { ence }\end{array}$ & $2 \mathrm{PO}$ & Yes & Endoscopy & PGME & 3,3 \\
\hline $\begin{array}{l}\text { 108- (Waterman BR, et } \\
\text { al.,2016) }\end{array}$ & Orthopedics & $2 \mathrm{PP}$ & Yes & Diagnostic Shoulder Arthroscopy & PGME & 12,10 \\
\hline 109- (Bloch A, et al.,2017) & Anesthesia and Analgesia & $2 \mathrm{PP}$ & Yes & Echocardiography & PGME & 22,21 \\
\hline 110-(Boza C, et al.,2017) & Surgical Endoscopy & $2 \mathrm{PP}$ & No & advanced laparoscopy & Both & $10,12,5$ \\
\hline 111- (Crochet P, et al.,2017) & Journal of Surgical Education & $\mathrm{CO}$ & No & Laparoscopic Suturing & PGME & 12,6 \\
\hline 112- (Dyre L, et al.,2017) & Medical Education & $2 \mathrm{PP}$ & Yes & Ultrasonics & UGME & 30,26 \\
\hline 113- (Lotfy M, et al.,2017) & Egyptian Journal of Surgery & $2 \mathrm{PP}$ & Yes & laparoscopic appendectomy & PGME & 15,15 \\
\hline 114- (Rosen H, et al.,2017) & $\begin{array}{c}\text { Journal of Obstetrics and } \\
\text { Gynaecology Canada }\end{array}$ & $2 \mathrm{PP}$ & Yes & Ultrasonography & PGME & 9,9 \\
\hline $\begin{array}{l}\text { 115- (Tolsgaard MG, et } \\
\text { al.,2017) }\end{array}$ & Annals of Surgery & $2 \mathrm{PO}$ & Yes & Ultrasonography & PGME & 26,26 \\
\hline $\begin{array}{l}\text { 116- (Maertens H, et } \\
\text { al.,2017) }\end{array}$ & $\begin{array}{l}\text { European Journal of Vascular } \\
\text { and Endovascular Surgery }\end{array}$ & $2 \mathrm{PP}$ & Yes & Endovascular skills & PGME & $9,10,10$ \\
\hline $\begin{array}{l}\text { 117- (Kallidaikurichi Srini- } \\
\text { vasan K, et al.,2018) }\end{array}$ & BMJ open & $2 \mathrm{PO}$ & Yes & Epidural Analgesia & PGME & 13,9 \\
\hline $\begin{array}{l}\text { 118- (Garfjeld Roberts P, et } \\
\text { al.,2019) }\end{array}$ & $\begin{array}{l}\text { Arthroscopy - journal of } \\
\text { arthroscopic and related } \\
\text { surgery }\end{array}$ & $2 \mathrm{PP}$ & Yes & diagnostic knee arthroscopy & PGME & 15,13 \\
\hline $\begin{array}{l}\text { 119- (Ostergaard ML, et } \\
\text { al.,2019) }\end{array}$ & European Radiology & $2 \mathrm{PO}$ & Yes & Ultrasonography & PGME & 11,9 \\
\hline $\begin{array}{l}\text { 120- (Popovic B, et } \\
\text { al.,2019) }\end{array}$ & $\begin{array}{c}\text { American Journal of Cardi- } \\
\text { ology }\end{array}$ & $2 \mathrm{PO}$ & Yes & Cardiac Catheterization & PGME & 10,10 \\
\hline 121- (Wong DT, et al.,2019) & $\begin{array}{c}\text { European Journal of Anaes- } \\
\text { thesiology }\end{array}$ & $2 \mathrm{PP}$ & Yes & bronchoscopic-guided intubation & Both & 16,15 \\
\hline
\end{tabular}


Appendix S3. Included papers for the review

1. Ewy GA, Felner JM, Juul D, Mayer JW, Sajid AW, Waugh RA. Test of a cardiology patient simulator with students in fourth-year electives. Journal of Medical Education. 1987;62(9):738-43.

2. Ovassapian A, Yelich SJ, Dykes MH, Golman ME. Learning fibreoptic intubation: use of simulators v. traditional teaching. British journal of anaesthesia. 1988;61(2):217-20.

3. From RP, Pearson KS, Albanese MA, Moyers JR, Sigurdsson SS, Dull DL. Assessment of an interactive learning system with "sensorized" manikin head for airway management instruction. Anesthesia and analgesia. 1994;79(1):136-42.

4. Peugnet F, Dubois P, Rouland JF. Virtual reality versus conventional training in retinal photocoagulation: a first clinical assessment. Computer Aided Surgery. 1998;3(1):20-6.

5. Tuggy ML. Virtual reality flexible sigmoidoscopy simulator training: impact on resident performance. The journal of the american board of family practice. 1998;11(6):426-33.

6. Scott DJ, Bergen PC, Rege RV, Laycock R, Tesfay ST, Valentine RJ, et al. Laparoscopic training on bench models: better and more cost effective than operating room experience? J Am Coll Surg. 2000;191(3):272-83.

7. Hamilton EC, Scott DJ, Kapoor A, Nwariaku F, Bergen PC, Rege RV, et al. Improving operative performance using a laparoscopic hernia simulator. American journal of surgery. 2001;182(6):725-8.

8. Naik VN, Matsumoto ED, Houston PL, Hamstra SJ, Yeung RY, Mallon JS, et al. Fiberoptic orotracheal intubation on anesthetized patients: do manipulation skills learned on a simple model transfer into the operating room? Anesthesiology. 2001;95(2):343-8.

9. Ost D, DeRosiers A, Britt EJ, Fein AM, Lesser ML, Mehta AC. Assessment of a bronchoscopy simulator. American journal of respiratory and critical care medicine. 2001;164(12):2248-55.

10. Edmond CV, Jr. Impact of the endoscopic sinus surgical simulator on operating room performance. Laryngoscope. 2002;112(7 Pt 1):1148-58.

11. Hamilton EC, Scott DJ, Fleming JB, Rege RV, Laycock R, Bergen $\mathrm{PC}$, et al. Comparison of video trainer and virtual reality training systems on acquisition of laparoscopic skills. Surgical endoscopy and other interventional techniques. 2002;16(3):406-11.

12. Rowe R, Cohen RA. An evaluation of a virtual reality airway simulator. Anesth Analg. 2002;95(1):62-6, table of contents.

13. Seymour NE, Gallagher AG, Roman SA, O'Brien MK, Bansal VK, Andersen DK, et al. Virtual reality training improves operating room performance: results of a randomized, double-blinded study. Annals of surgery. 2002;236(4):458-63; discussion 63-4.

14. Gerson LB, Van Dam J. A prospective randomized trial comparing a virtual reality simulator to bedside teaching for training in sigmoidoscopy. Endoscopy. 2003;35(7):569-75.

15. Gormley GJ, Steele WK, Stevenson M, McKane R, Ryans I, Cairns $\mathrm{AP}$, et al. A randomised study of two training programmes for general practitioners in the techniques of shoulder injection. Annals of the rheumatic diseases. 2003;62(10):1006-9.

16. Lee SK, Pardo M, Gaba D, Sowb Y, Dicker R, Straus EM, et al. Trauma assessment training with a patient simulator: a prospective, randomized study. Journal of trauma. 2003;55(4):651-7.

17. Abrahamson S, Denson JS, Wolf RM. Effectiveness of a simulator in training anesthesiology residents. 1969. Quality \& safety in health care. 2004;13(5):395-7.

18. Blum MG, Powers TW, Sundaresan S. Bronchoscopy simulator effectively prepares junior residents to competently perform basic clinical bronchoscopy. Annals of thoracic surgery. 2004;78(1):287-91; discussion -91 .

19. Di Giulio E, Fregonese D, Casetti T, Cestari R, Chilovi F, D'Ambra $\mathrm{G}$, et al. Training with a computer-based simulator achieves basic manual skills required for upper endoscopy: a randomized controlled trial. Gastrointestinal endoscopy. 2004;60(2):196-200.

20. Grantcharov TP, Kristiansen VB, Bendix J, Bardram L, Rosenberg J, Funch-Jensen P. Randomized clinical trial of virtual reality simulation for laparoscopic skills training. British journal of surgery. 2004;91(2):146-50.

21. Sedlack RE, Kolars JC. Computer simulator training enhances the competency of gastroenterology fellows at colonoscopy: results of a pilot study. American journal of gastroenterology. 2004;99(1):33-7.

22. Sedlack RE, Kolars JC, Alexander JA. Computer simulation training enhances patient comfort during endoscopy. Clin Gastroenterol Hepa- tol. $2004 ; 2(4): 348-52$

23. Ahlberg G, Hultcrantz R, Jaramillo E, Lindblom A, Arvidsson D. Virtual reality colonoscopy simulation: a compulsory practice for the future colonoscopist? Endoscopy. 2005;37(12):1198-204.

24. Hochberger J, Matthes K, Maiss J, Koebnick C, Hahn EG, Cohen J. Training with the compactEASIE biologic endoscopy simulator significantly improves hemostatic technical skill of gastroenterology fellows: a randomized controlled comparison with clinical endoscopy training alone. Gastrointestinal endoscopy. 2005;61(2):204-15.

25. Schijven MP, Jakimowicz JJ, Broeders IA, Tseng LN. The Eindhoven laparoscopic cholecystectomy training course--improving operating room performance using virtual reality training: results from the first E.A.E.S. accredited virtual reality trainings curriculum. Surg Endosc. 2005;19(9):1220-6

26. Stitik TP, Foye PM, Nadler SF, Chen B, Schoenherr L, Von Hagen $\mathrm{S}$. Injections in patients with osteoarthritis and other musculoskeletal disorders: use of synthetic injection models for teaching physiatry residents. American journal of physical medicine \& rehabilitation. 2005;84(7):550-9.

27. Banks E, Pardanani S, King M, Chudnoff S, Damus K, Freda MC. A surgical skills laboratory improves residents' knowledge and performance of episiotomy repair. Am J Obstet Gynecol. 2006;195(5):14637.

28. Chaer RA, Derubertis BG, Lin SC, Bush HL, Karwowski JK, Birk $\mathrm{D}$, et al. Simulation improves resident performance in catheter-based intervention: results of a randomized, controlled study. Annals of surgery. 2006;244(3):343-52.

29. Cohen J, Cohen SA, Vora KC, Xue X, Burdick JS, Bank S, et al. Multicenter, randomized, controlled trial of virtual-reality simulator training in acquisition of competency in colonoscopy. Gastrointestinal endoscopy. 2006;64(3):361-8.

30. Scerbo MW, Schmidt EA, Bliss JP. Comparison of a virtual reality simulator and simulated limbs for phlebotomy training. Journal of Infusion Nursing. 2006;29(4):214-24

31. Ahlberg G, Enochsson L, Gallagher AG, Hedman L, Hogman C, McClusky DA, et al. Proficiency-based virtual reality training significantly reduces the error rate for residents during their first 10 laparoscopic cholecystectomies. American journal of surgery. 2007;193(6):797-804

32. Banks EH, Chudnoff S, Karmin I, Wang C, Pardanani S. Does a surgical simulator improve resident operative performance of laparoscopic tubal ligation? American journal of obstetrics and gynecology. 2007;197(5):541.e1-5.

33. Cosman PH, Hugh TJ, Shearer CJ, Merrett ND, Biankin AV, Cartmill JA. Skills acquired on virtual reality laparoscopic simulators transfer into the operating room in a blinded, randomised, controlled trial. Studies in health technology and informatics. 2007;125:76-81.

34. Miranda JA, Trick WE, Evans AT, Charles-Damte M, Reilly BM, Clarke P. Firm-based trial to improve central venous catheter insertion practices. J Hosp Med. 2007;2(3):135-42.

35. Park J, MacRae H, Musselman LJ, Rossos P, Hamstra SJ, Wolman $\mathrm{S}$, et al. Randomized controlled trial of virtual reality simulator training: transfer to live patients. American journal of surgery. 2007;194(2):205-11.

36. Shavit I, Keidan I, Hoffmann Y, Mishuk L, Rubin O, Ziv A, et al. Enhancing patient safety during pediatric sedation: the impact of simulation-based training of nonanesthesiologists. Archives of Pediatrics \& Adolescent Medicine. 2007;161(8):740-3.

37. Thomas-Gibson S, Bassett P, Suzuki N, Brown GJ, Williams CB, Saunders BP. Intensive training over 5 days improves colonoscopy skills long-term. Endoscopy. 2007;39(9):818-24.

38. Draycott TJ, Crofts JF, Ash JP, Wilson LV, Yard E, Sibanda T, et al. Improving neonatal outcome through practical shoulder dystocia training. Obstet Gynecol. 2008;112(1):14-20.

39. Howells NR, Gill HS, Carr AJ, Price AJ, Rees JL. Transferring simulated arthroscopic skills to the operating theatre: a randomised blinded study. Journal of bone and joint surgery. 2008;British volume. 90(4):494-9.

40. Ossowski KL, Rhee DC, Rubinstein EN, Ferguson BJ. Efficacy of sinonasal simulator in teaching endoscopic nasal skills. Laryngoscope. 2008;118(8):1482-5.

41. Van Sickle KR, Ritter EM, Baghai M, Goldenberg AE, Huang IP, Gallagher AG, et al. Prospective, randomized, double-blind trial of curriculum-based training for intracorporeal suturing and knot tying. Journal of the american college of surgeons. 2008;207(4):560-8. 
42. Wayne DB, Didwania A, Feinglass J, Fudala MJ, Barsuk JH, McGaghie WC. Simulation-based education improves quality of care during cardiac arrest team responses at an academic teaching hospital: a case-control study. Chest. 2008;133(1):56-61.

43. Yi SY, Ryu KH, Na YJ, Woo HS, Ahn W, Kim WS, et al. Improvement of colonoscopy skills through simulation-based training. Studies in Health Technology \& Informatics. 2008;132:565-7.

44. Barsuk JH, Cohen ER, Feinglass J, McGaghie WC, Wayne DB. Use of simulation-based education to reduce catheter-related bloodstream infections. Archives of Internal Medicine. 2009;169(15):1420-3.

45. Barsuk JH, McGaghie WC, Cohen ER, Balachandran JS, Wayne DB. Use of simulation-based mastery learning to improve the quality of central venous catheter placement in a medical intensive care unit. J Hosp Med. 2009;4(7):397-403.

46. Barsuk JH, McGaghie WC, Cohen ER, O'Leary KJ, Wayne DB. Simulation-based mastery learning reduces complications during central venous catheter insertion in a medical intensive care unit. Crit Care Med. 2009;37(10):2697-701.

47. Britt RC, Novosel TJ, Britt LD, Sullivan M. The impact of central line simulation before the ICU experience. American journal of surgery. 2009;197(4):533-6.

48. Domuracki KJ, Moule CJ, Owen H, Kostandoff G, Plummer JL. Learning on a simulator does transfer to clinical practice. Resuscitation. 2009;80(3):346-9.

49. Friedman Z, Siddiqui N, Katznelson R, Devito I, Bould MD, Naik V. Clinical impact of epidural anesthesia simulation on short- and longterm learning curve: high- versus low-fidelity model training. Regional anesthesia and pain medicine. 2009;34(3):229-32.

50. Gaies MG, Morris SA, Hafler JP, Graham DA, Capraro AJ, Zhou J, et al. Reforming procedural skills training for pediatric residents: a randomized, interventional trial. Pediatrics. 2009;124(2):610-9.

51. Hogle NJ, Chang L, Strong VEM, Welcome AOU, Sinaan M, Bailey $\mathrm{R}$, et al. Validation of laparoscopic surgical skills training outside the operating room: A long road. Surgical Endoscopy. 2009;23(7):147682 .

52. Larsen CR, Soerensen JL, Grantcharov TP, Dalsgaard T, Schouenborg L, Ottosen C, et al. Effect of virtual reality training on laparoscopic surgery: randomised controlled trial. Bmj. 2009;338.

53. Mohan PVR, Chaudhry R. Laparoscopic simulators: Are they useful! Medical Journal Armed Forces India. 2009;65(2):113-7.

54. Sotto JA, Ayuste EC, Bowyer MW, Almonte JR, Dofitas RB, Lapi$\tan \mathrm{MC}$, et al. Exporting simulation technology to the Philippines: a comparative study of traditional versus simulation methods for teaching intravenous cannulation. Stud Health Technol Inform. 2009;142:346-51.

55. Bruppacher HR, Alam SK, LeBlanc VR, Latter D, Naik VN, Savoldelli GL, et al. Simulation-based training improves physicians' performance in patient care in high-stakes clinical setting of cardiac surgery. Anesthesiology. 2010;112(4):985-92.

56. Butter J, McGaghie WC, Cohen ER, Kaye M, Wayne DB. Simulation-based mastery learning improves cardiac auscultation skills in medical students. Journal of general internal medicine. 2010;25(8):780-5.

57. Evans LV, Dodge KL, Shah TD, Kaplan LJ, Siegel MD, Moore CL, et al. Simulation training in central venous catheter insertion: improved performance in clinical practice. Academic medicine. 2010;85(9):1462-9.

58. Ferlitsch A, Schoefl R, Puespoek A, Miehsler W, Schoeniger-Hekele $\mathrm{M}$, Hofer $\mathrm{H}$, et al. Effect of virtual endoscopy simulator training on performance of upper gastrointestinal endoscopy in patients: a randomized controlled trial. Endoscopy. 2010;42(12):1049-56.

59. Fried MP, Sadoughi B, Gibber MJ, Jacobs JB, Lebowitz RA, Ross $\mathrm{DA}$, et al. From virtual reality to the operating room: the endoscopic sinus surgery simulator experiment. Otolaryngology--head and neck surgery. 2010;142(2):202-7.

60. Gauger PG, Hauge LS, Andreatta PB, Hamstra SJ, Hillard ML, Arble EP, et al. Laparoscopic simulation training with proficiency targets improves practice and performance of novice surgeons. American journal of surgery. 2010;199(1):72-80.

61. Haycock A, Koch AD, Familiari P, van Delft F, Dekker E, Petruzziello L, et al. Training and transfer of colonoscopy skills: a multinational, randomized, blinded, controlled trial of simulator versus bedside training. Gastrointestinal endoscopy. 2010;71(2):298-307.

62. Kallstrom R, Hjertberg H, Svanvik J. Impact of virtual realitysimulated training on urology residents' performance of transurethral resection of the prostate. J Endourol. 2010;24(9):1521-8.

63. Lenchus JD. End of the "see one, do one, teach one" era: the next generation of invasive bedside procedural instruction. J Am Osteopath Assoc. 2010;110(6):340-6.

64. Schout BM, Ananias HJ, Bemelmans BL, d'Ancona FC, Muijtjens AM, Dolmans VE, et al. Transfer of cysto-urethroscopy skills from a virtual-reality simulator to the operating room: a randomized controlled trial. BJU international. 2010;106(2):226-31; discussion 31 .

65. Sroka G, Feldman LS, Vassiliou MC, Kaneva PA, Fayez R, Fried GM. Fundamentals of laparoscopic surgery simulator training to proficiency improves laparoscopic performance in the operating room-a randomized controlled trial. American journal of surgery. 2010;199(1):115-20.

66. Tongprasert F, Wanapirak C, Sirichotiyakul S, Piyamongkol W, Tongsong T. Training in cordocentesis: the first 50 case experience with and without a cordocentesis training model. Prenat Diagn. 2010;30(5):467-70.

67. Wahidi MM, Silvestri GA, Coakley RD, Ferguson JS, Shepherd RW, Moses L, et al. A prospective multicenter study of competency metrics and educational interventions in the learning of bronchoscopy among new pulmonary fellows. Chest. 2010;137(5):1040-9.

68. De Ponti R, Marazzi R, Ghiringhelli S, Salerno-Uriarte JA, Calkins $\mathrm{H}$, Cheng A. Superiority of simulator-based training compared with conventional training methodologies in the performance of transseptal catheterization. Journal of the american college of cardiology. 2011;58(4):359-63.

69. Ghaderi I, Vaillancourt M, Sroka G, Kaneva PA, Seagull FJ, George I, et al. Performance of simulated laparoscopic incisional hernia repair correlates with operating room performance. American journal of surgery. 2011;201(1):40-5.

70. Johnson SJ, Guediri SM, Kilkenny C, Clough PJ. Development and validation of a virtual reality simulator: Human factors input to interventional radiology training. Human Factors. 2011;53(6):612-25.

71. Khouli H, Jahnes K, Shapiro J, Rose K, Mathew J, Gohil A, et al. Performance of medical residents in sterile techniques during central vein catheterization: randomized trial of efficacy of simulation-based training. Chest. 2011;139(1):80-7.

72. Palter VN, Grantcharov T, Harvey A, Macrae HM. Ex vivo technical skills training transfers to the operating room and enhances cognitive learning: a randomized controlled trial. Annals of surgery. 2011;253(5):886-9.

73. Zendejas B, Cook DA, Bingener J, Huebner M, Dunn WF, Sarr MG, et al. Simulation-based mastery learning improves patient outcomes in laparoscopic inguinal hernia repair: a randomized controlled trial. Annals of surgery. 2011;254(3):502-9; discussion 9-11.

74. Ahya SN, Barsuk JH, Cohen ER, Tuazon J, McGaghie WC, Wayne DB. Clinical Performance and Skill Retention after Simulation-based Education for Nephrology Fellows. Seminars in Dialysis. 2012;25(4):470-3.

75. Bagai A, O'Brien S, Al Lawati H, Goyal P, Ball W, Grantcharov T, et al. Mentored simulation training improves procedural skills in cardiac catheterization: a randomized, controlled pilot study. Circulation. 2012; Cardiovascular interventions. 5(5):672-9.

76. Ende A, Zopf Y, Konturek P, Naegel A, Hahn EG, Matthes K, et al. Strategies for training in diagnostic upper endoscopy: a prospective, randomized trial. Gastrointestinal endoscopy. 2012;75(2):254-60.

77. Franzeck FM, Rosenthal R, Muller MK, Nocito A, Wittich F, Maurus C, et al. Prospective randomized controlled trial of simulatorbased versus traditional in-surgery laparoscopic camera navigation training. Surgical endoscopy. 2012;26(1):235-41.

78. Fried MP, Kaye RJ, Gibber MJ, Jackman AH, Paskhover BP, Sadoughi B, et al. Criterion-based (proficiency) training to improve surgical performance. Archives of otolaryngology--head \& neck surgery. 2012;138(11):1024-9.

79. Hseino H, Nugent E, Lee MJ, Hill AD, Neary P, Tierney S, et al. Skills transfer after proficiency-based simulation training in superficial femoral artery angioplasty. Simulation in healthcare. 2012;7(5):27481 .

80. Orzech N, Palter VN, Reznick RK, Aggarwal R, Grantcharov TP. A comparison of 2 ex vivo training curricula for advanced laparoscopic skills: a randomized controlled trial. Annals of surgery 2012;255(5):833-9.

81. Palter VN, Grantcharov TP. Development and validation of a comprehensive curriculum to teach an advanced minimally invasive procedure: a randomized controlled trial. Annals of surgery. 
2012;256(1):25-32.

82. Stather DR, MacEachern P, Chee A, Dumoulin E, Tremblay A. Evaluation of clinical endobronchial ultrasound skills following clinical versus simulation training. Respirology. 2012;17(2):291-9.

83. White ML, Jones R, Zinkan L, Tofil NM. Transfer of simulated lumbar puncture training to the clinical setting. Pediatric Emergency Care. 2012;28(10):1009-12.

84. Daly MK, Gonzalez E, Siracuse-Lee D, Legutko PA. Efficacy of surgical simulator training versus traditional wet-lab training on operating room performance of ophthalmology residents during the capsulorhexis in cataract surgery. Journal of cataract and refractive surgery. 2013;39(11):1734-41.

85. Gala R, Orejuela F, Gerten K, Lockrow E, Kilpatrick C, Chohan L, et al. Effect of validated skills simulation on operating room performance in obstetrics and gynecology residents: a randomized controlled trial. Obstetrics and gynecology. 2013;121(3):578-84.

86. Palter VN, Orzech N, Reznick RK, Grantcharov TP. Validation of a structured training and assessment curriculum for technical skill acquisition in minimally invasive surgery: a randomized controlled trial. Annals of surgery. 2013;257(2):224-30.

87. Pokroy R, Du E, Alzaga A, Khodadadeh S, Steen D, Bachynski B, et al. Impact of simulator training on resident cataract surgery. Graefes Archive for Clinical \& Experimental Ophthalmology. 2013;251(3):777-81.

88. Todsen T, Henriksen MV, Kromann CB, Konge L, Eldrup J, Ringsted C. Short- and long-term transfer of urethral catheterization skills from simulation training to performance on patients. BMC medical education. 2013;13(29).

89. Balci MBC, Tas T, Hazar AI, Aydin M, Onuk O, Cakiroglu B, et al. Applicability and effectiveness of virtual reality simulator training in urologic surgery: a double-blind randomised study. Nobel medicus. 2014;10(2):66-71.

90. Bansal VK, Raveendran R, Misra MC, Bhattacharjee H, Rajan K, Krishna A, et al. A prospective randomized controlled blinded study to evaluate the effect of short-term focused training program in laparoscopy on operating room performance of surgery residents (CTRI /2012/11/003113). Journal of surgical education. 2014;71(1):52-60.

91. Cannon WD, Garrett WE, Hunter RE, Sweeney HJ, Eckhoff DG, Nicandri GT, et al. Improving residency training in arthroscopic knee surgery with use of a virtual-reality simulator. A randomized blinded study. Journal of bone and joint surgery. 2014;American volume. 96(21):1798-806.

92. Edrich T, Seethala RR, Olenchock BA, Mizuguchi AK, Rivero JM, Beutler SS, et al. Providing initial transthoracic echocardiography training for anesthesiologists: simulator training is not inferior to live training. Journal of cardiothoracic and vascular anesthesia. 2014;28(1):49-53.

93. Ferrero NA, Bortsov AV, Arora H, Martinelli SM, Kolarczyk LM, Teeter EC, et al. Simulator training enhances resident performance in transesophageal echocardiography. Anesthesiology. 2014;120(1):149 59.

94. Hong P, Webb AN, Corsten G, Balderston J, Haworth R, Ritchie K, et al. An anatomically sound surgical simulation model for myringotomy and tympanostomy tube insertion. Int J Pediatr Otorhinolaryngol. 2014;78(3):522-9.

95. McIntosh KS, Gregor JC, Khanna NV. Computer-based virtual reality colonoscopy simulation improves patient-based colonoscopy performance. Canadian journal of gastroenterology \& hepatology. 2014;28(4):203-6

96. Minai F, Shafiq F, Ul Haq MI. Value of real life (in situ) simulation training for tracheal intubation skills in medical undergraduates during short duration anesthesia rotation. Journal of anaesthesiology, clinical pharmacology. 2014;30(4):484-7.

97. Palter VN, Grantcharov TP. Individualized deliberate practice on a virtual reality simulator improves technical performance of surgical novices in the operating room: a randomized controlled trial. Annals of surgery. 2014;259(3):443-8.

98. Udani AD, Macario A, Nandagopal K, Tanaka MA, Tanaka PP Simulation-Based Mastery Learning with Deliberate Practice Improves Clinical Performance in Spinal Anesthesia. Anesthesiology research and practice. 2014;2014

99. Grover SC, Garg A, Scaffidi MA, Yu JJ, Plener IS, Yong E, et al. Impact of a simulation training curriculum on technical and nontechnical skills in colonoscopy: a randomized trial. Gastrointestinal endoscopy. 2015;82(6):1072-9.
100. Koch AD, Ekkelenkamp VE, Haringsma J, Schoon EJ, de Man RA, Kuipers EJ. Simulated colonoscopy training leads to improved performance during patient-based assessment. Gastrointestinal endoscopy. 2015;81(3):630-6.

101. Peltan ID, Shiga T, Gordon JA, Currier PF. Simulation Improves Procedural Protocol Adherence During Central Venous Catheter Placement: a Randomized Controlled Trial. Simulation in healthcare. 2015;10(5):270-6

102. Tolsgaard MG, Madsen ME, Ringsted C, Oxlund BS, Oldenburg A, Sorensen JL, et al. The effect of dyad versus individual simulationbased ultrasound training on skills transfer. Medical education. 2015;49(3):286-95

103. Aloosh M, Noureldin YA, Andonian S. Transfer of Flexible Ureteroscopic Stone-Extraction Skill from a Virtual Reality Simulator to the Operating Theatre: A Pilot Study. Journal of Endourology. 2016;30(10):1120-5.

104. Arias T, Tran A, Breaud J, Fournier JP, Bongain A, Delotte J. A prospective study into the benefits of simulation training in teaching obstetric vaginal examination. International journal of gynaecology and obstetrics. 2016;133(3):380-4

105. Asoglu MR, Achjian T, Akbilgic O, Borahay MA, Kilic GS. The impact of a simulation-based training lab on outcomes of hysterectomy. Journal of the Turkish-German Gynecological Association. 2016;17(2):60-4.

106. Jaffer U, Normahani P, Matyushev N, Aslam M, Standfield NJ. Intensive Simulation Training in Lower Limb Arterial Duplex Scanning Leads to Skills Transfer in Real-World Scenario. Journal of Surgical Education. 2016;73(3):453-60.

107. Thawani JP, Ramayya AG, Abdullah KG, Hudgins E, Vaughan K, Piazza M, et al. Resident simulation training in endoscopic endonasal surgery utilizing haptic feedback technology. Journal of clinical neuroscience. 2016;34:112-6.

108. Waterman BR, Martin KD, Cameron KL, Owens BD, Belmont PJ. Simulation Training Improves Surgical Proficiency and Safety During Diagnostic Shoulder Arthroscopy Performed by Residents. Orthopedics. 2016;39(3):e479-85.

109. Bloch A, von Arx R, Etter R, Berger D, Kaiser H, Lenz A, et al. Impact of Simulator-Based Training in Focused Transesophageal Echocardiography: a Randomized Controlled Trial. Anesthesia and analgesia. 2017;125(4):1140-8.

110. Boza C, Leon F, Buckel E, Riquelme A, Crovari F, Martinez J, et al. Simulation-trained junior residents perform better than general surgeons on advanced laparoscopic cases. Surg Endosc. 2017;31(1):13541.

111. Crochet P, Agostini A, Knight S, Resseguier N, Berdah S, Aggarwal R. The Performance Gap for Residents in Transfer of Intracorporeal Suturing Skills From Box Trainer to Operating Room. Journal of Surgical Education. 2017;74(6):1019-27.

112. Dyre L, Tabor A, Ringsted C, Tolsgaard MG. Imperfect practice makes perfect: error management training improves transfer of learning. Medical education. 2017;51(2):196-206.

113. Lotfy M, Abdelhamid MI, Ashri HN. A comparative study on the effect of laparoscopic simulation on skill training in laparoscopic surgery. Egyptian Journal of Surgery. 2017;36(4):336-9.

114. Maertens H, Aggarwal R, Moreels N, Vermassen F, Van Herzeele I. A Proficiency Based Stepwise Endovascular Curricular Training (PROSPECT) Program Enhances Operative Performance in Real Life: A Randomised Controlled Trial. European Journal of Vascular and Endovascular Surgery. 2017;54(3):387-96.

115. Rosen H, Windrim R, Lee YM, Gotha L, Perelman V, Ronzoni S. Simulator Based Obstetric Ultrasound Training: a Prospective, Randomized Single-Blinded Study. J Obstet Gynaecol Can. 2017;39(3):166-73.

116. Tolsgaard MG, Ringsted C, Rosthoj S, Norgaard L, Moller L, La Cour Freiesleben N, et al. The Effects of Simulation-based Transvaginal Ultrasound Training on Quality and Efficiency of Care: A Multicenter Single-blind Randomized Trial. Annals of surgery. 2017;265(3):630-7

117. Kallidaikurichi Srinivasan K, Gallagher A, O'Brien N, Sudir V, Barrett N, O'Connor R, et al. Proficiency-based progression training: an 'end to end' model for decreasing error applied to achievement of effective epidural analgesia during labour: a randomised control study. BMJ open. 2018;8(10):e020099.

118. Garfjeld Roberts P, Alvand A, Gallieri M, Hargrove C, Rees J. Objectively Assessing Intraoperative Arthroscopic Skills Performance 
and the Transfer of Simulation Training in Knee Arthroscopy: a Randomized Controlled Trial. Arthroscopy - journal of arthroscopic and related surgery. 2019;35(4):1197-209.e1.

119. Ostergaard ML, Rue Nielsen K, Albrecht-Beste E, Kjaer Ersboll A, Konge L, Bachmann Nielsen M. Simulator training improves ultrasound scanning performance on patients: a randomized controlled trial. European radiology. 2019;29(6):3210-8.

120. Popovic B, Pinelli S, Albuisson E, Metzdorf PA, Mourer B, Tran N, et al. The Simulation Training in Coronary Angiography and Its Im- pact on Real Life Conduct in the Catheterization Laboratory. American journal of cardiology. 2019;123(8):1208-13.

121. Wong DT, Mehta A, Singh KP, Leong SM, Ooi A, Niazi A, et al. The effect of virtual reality bronchoscopy simulator training on performance of bronchoscopic-guided intubation in patients: a randomised controlled trial. European journal of anaesthesiology. 2019;36(3):227-33.

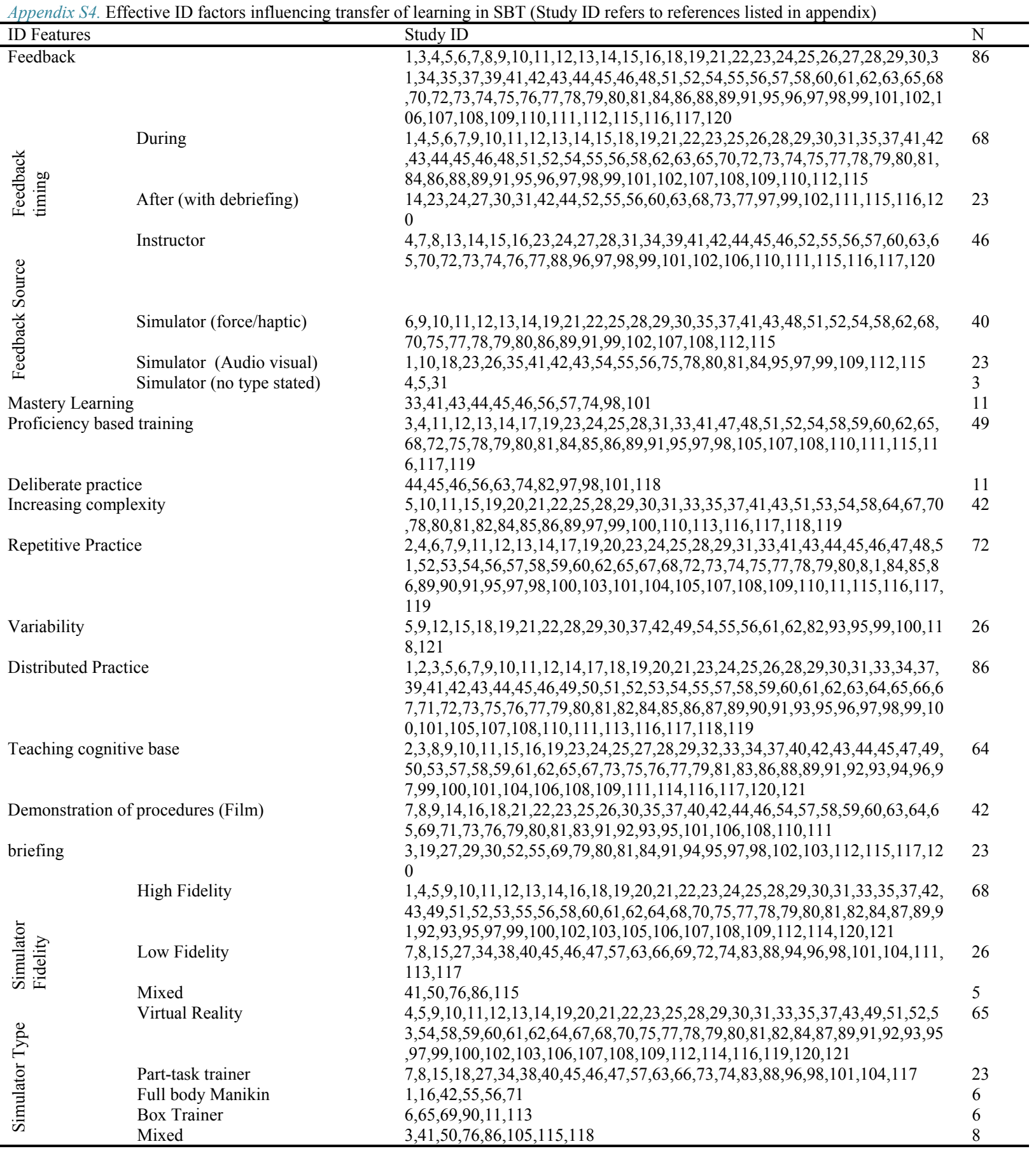


Transfer of learning in simulation-based training

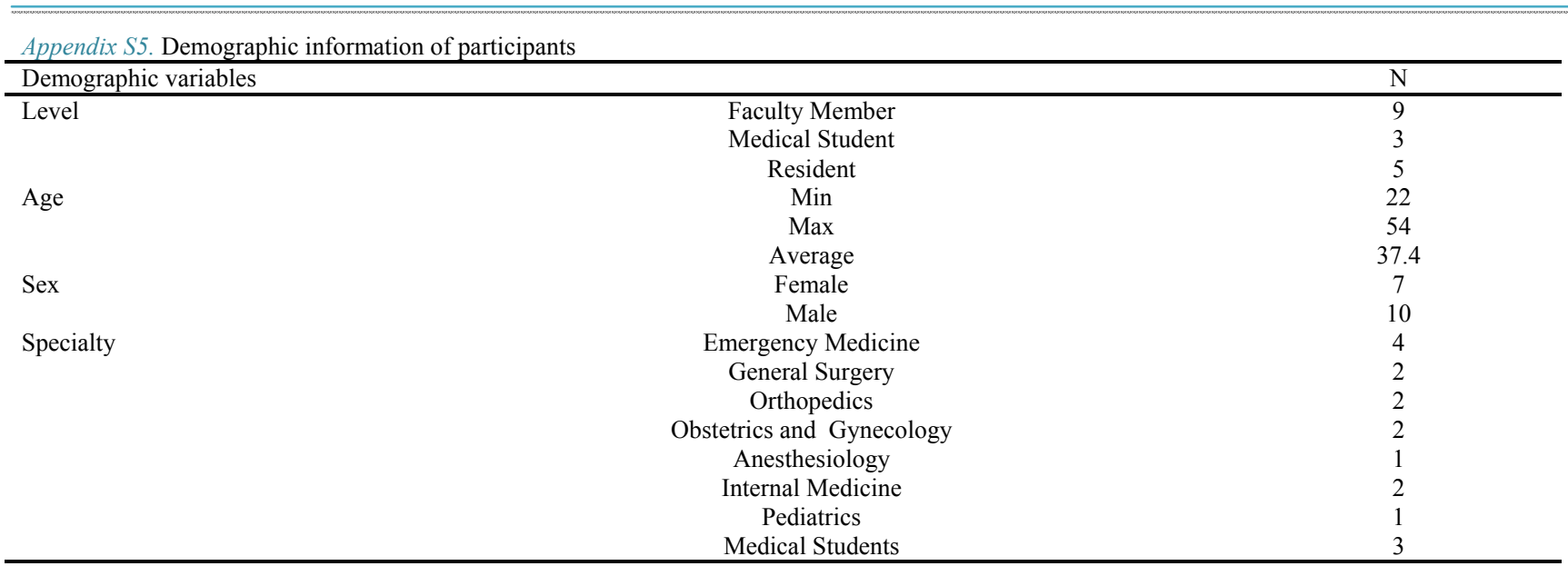

